

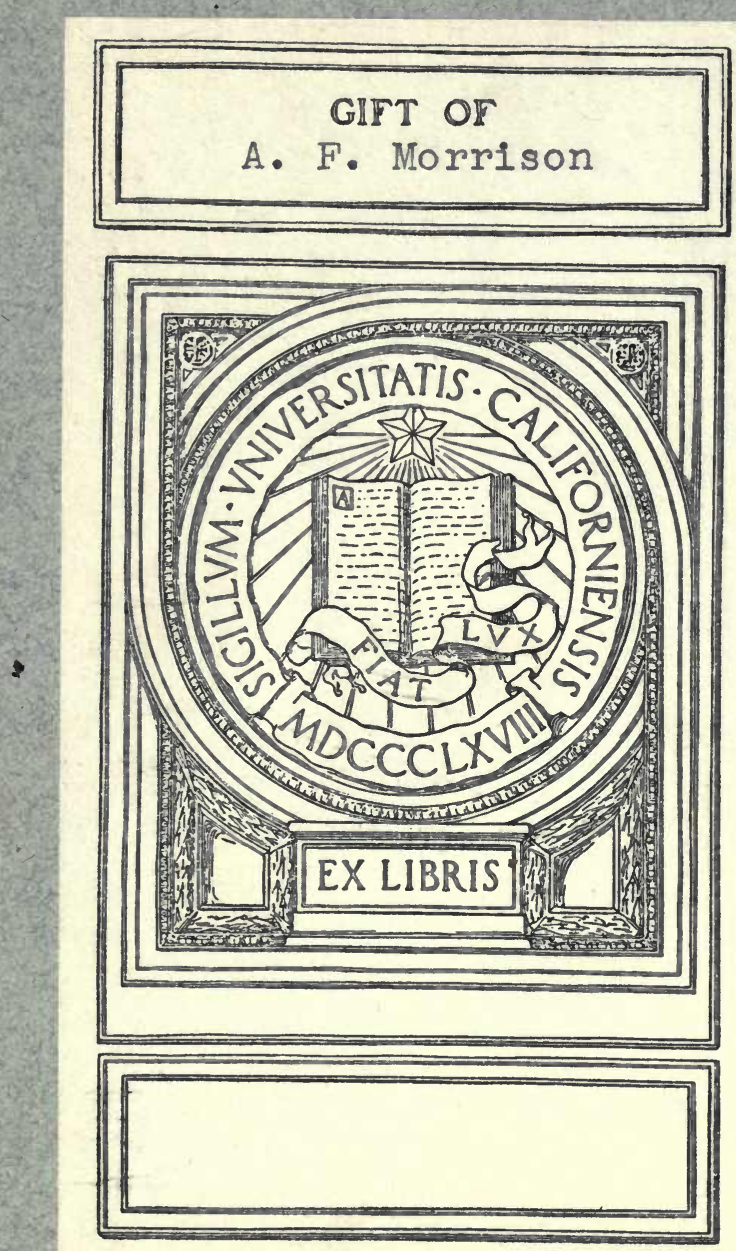




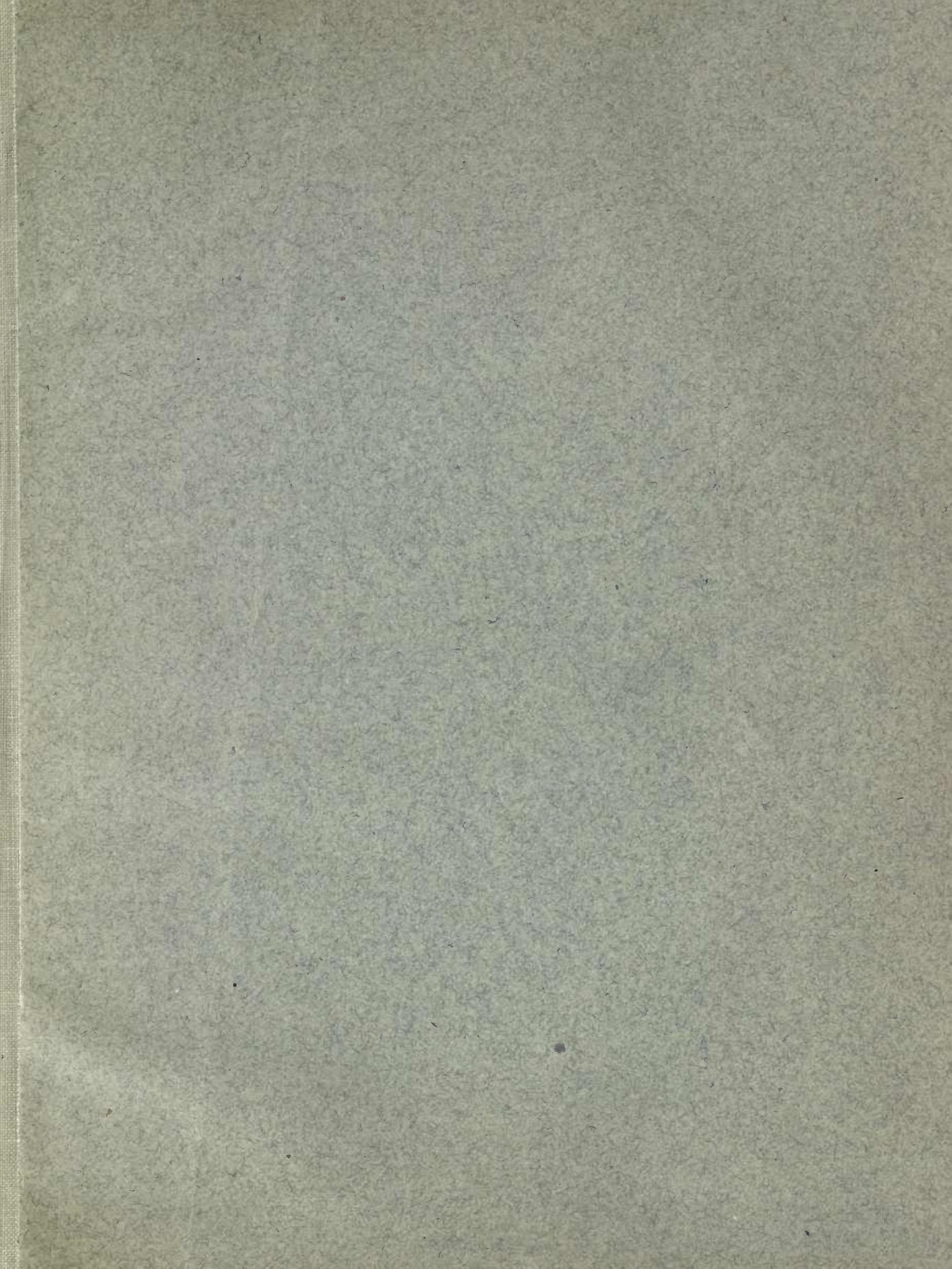





THE

\section{Varieties of Dogs,}

AS THEY ARE FOUND IN OLD SCULPTURES, PICTURES, ENGRAVINGS, AND BOOKS.

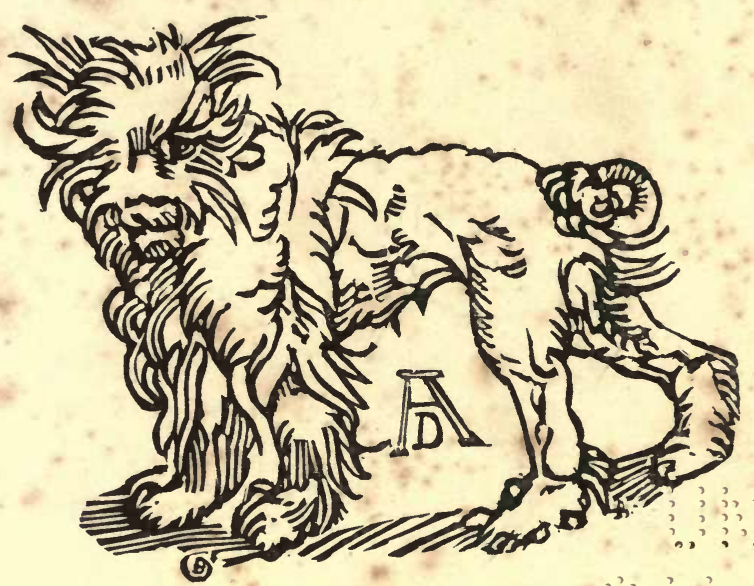

With the Names of the Artifts by whom they are reprefented, fhowing how long many of the numerous Breeds now exifting have been known.

By PH. CHARLES BERJEAU. 11

LONDON :

DULAU \& CO. 37 Soho Seuare. 1863. 

TO

\section{JOHN B. INGLIS, ESQ.}

\section{Cbis đatork}

IS RESPECTFULLY DEDICATED

BY

HIS OBEDIENT AND FAITHFUL SERVANT,

Ph. CHARLES BERJEAU. 

THE

\section{VARIETIES OF DOGS.}

" Lo, the poor Indian

But thinks, admitted to that equal $1 k y$,

His faithful dog thall bear him company."

EDay on Man, Ep. I.

THE fidelity of dogs is fo much more proverbial than that of their

1 mafters, that an inftance equally honourable to both is worth knowing. The chariot of Indru was waiting to carry Yoodhifthuru to heaven; he came to the place, his dog following. "I don't take dogs," fays Indru. "Then I don't go," replies Yoodhift'huru. The dog, however, turned out to be Humu, a god, and the difficulty was got over.*

But we do not pretend to confider dogs in a theological point of view. We will fimply ftate here to what purpofe we prefent in the following plates the varieties of dogs as found in antique marbles, in 
books;: drawings, :and pictures, down to the $17^{\text {th }}$ century. According to Darwin's Thbory of Selection, the forms of animals are, in the courfe offage: modified by: climate and habits, even when their fpecies may be brought back to a type almoft unique, and not complicated as regards fize and general outline of the body. Are fuch modifications highly obfervable in dogs, of which the common type may be, and is, in fact, varied almoft ad infinitum by crofs-breedings? Such is the quettion which the prefent book will, perhaps, help to bring a little nearer its folution.

Some of the greateft artifts feem to have had a particular fancy for dogs, and they have, without doubt, given correct likeneffes of fuch as they have drawn. The infpection of their drawings, collected from every available fource, and reproduced as much as poffible in fac-fimile, muft, therefore, be acceptable to all who take an intereft in fuch queftions.

The laft exhibition of fporting and other dogs which we have juft witneffed in the laft week of March 1863, confifting of more than 1200 dogs, very fairly reprefented all the varieties now extant in England. Let us enumerate here the varieties exhibited as a point of comparifon with our drawings, in which, certainly, the greater part of thefe varieties may be ftill recognifed.

The firft divifion, fporting dogs, fhowed us :
1. The fox-hound.
2. The fox-terrier.
7. The beagle.
3 The bloodhound.
4. 'The otter-hound.
5. The deer-hound.
6. The harrier.
8. The greyhound.
9. The pointer.
10. The fetter.
11. The black and tan fetter.

12. The Irifh fetter.

13. The retriever.

14. The Rufian retriever.

15. The Clumber fpaniel.

16. The fpaniel. 


\section{7}

The fecond divifion, dogs not ufed in field fports, included the reft of the canine varieties :

17. The maftiff dog.

18. The Newfoundland.

19. The St. Bernard dog.

20. The Dalmatian.

21. The large fize bull-dog.

22. The fmall fize bull-dog.

23. The bull terrier.

24. The black and tan terrier.
25. The white Englifh terrier.

26. The Englifh terrier.

27. The white Scotch terrier.

28. The fawn Scotch terrier.

29. The blue Scotch terrier.

30. The Skye terrier.

31. The Dandy Dinmont.

32. The pug dog.
33. The Italian greyhound.

34. The Blenheim fpaniel.

35. The King Charles's fpaniel.

36. The Maltefe dog.

37. The Scotch colley.

38. The French poodle.

39. The Efquimaux dog.

40. The Pomeranian dog.

Among the large foreign dogs were:

41. A truffle-hunter.

42. A Ruflian dog.

43. A boar-hound.

44. A Labrador dog.
45. A Secellan wolf-hound. 46. A reindeer or elk dog.

47. A hyæna and wolf-hound.

48. A wolf and fox-hound.
49. A Danifh boar-hound.

50. An Auftralian dog.

51. A Pruffian terrier.

52. A Turkin dog.

Among the fmall foreign dogs were :

53. A Cuba fpaniel. And

54. A dog fuppofed to be a variety of the wild prairie dog of India.

Leaving to the fportfman and to the artift, to find in the drawings the varieties which beft correfpond with thofe above enumerated, we will now point out more fully than it could be done under the drawings, the fources from which they are derived.

Marco Polo found in Thibet dogs of the fize of affes, ftrong enough to hunt all forts of wild beafts. The Affyrian dog (Plate I), taken from a wild-afs hunt in one of the baf-reliefs of Nineveh at the Britifh Mufeum, perhaps belonged to this variety, which Turner, 


\section{8}

in his Embafy to Thibet, faw in a row of wooden cages, and defcribes as " huge dogs, tremendoufly fierce, ftrong, and noify." The following (Plates 2 and 3), drawn from the antique, are more like bloodhounds, while the type of the greyhound is eafily traced to thofe of Plate 4, likewife drawn from an antique ftatue of Acteon, in the Britifh Mufeum.

The French poodle (Plate 5), copied from a curious engraving in the Print-room of the Britilh Mufeum, by an unknown French mafter, is accompanied by the following curious infcription. Above his head, in a fcroll, is :

\section{Ie suis Loyal Barbet veillant.}

And under him:

Le fage nous enfeigne, et di ce que f'enfuit.

Qui veut entrer dās la maifon

Il doit hurter premieremēt, En ouurāt dire fa raifon

Car f'il y entre lourdement On crira, Barbet arrefte.

Crie, mord-le hardiment, Car c'eft comme toy vne befte.

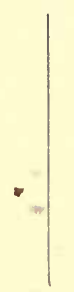

Dans la maifon entre maints fots Pour y prendre où crocheter, D'autre f'en vont voir dans le pot, Qu'il y a pour le rapporter Telz fots ont gaigne le frotter Ils font bien aifez a cognoitre Car font ennemis de mon maiftre.

Le bon chien domeftique veille, cependant que fon maiftre dort, Et f'il vient quelqu'un il l'eveille, quand par fortune il dort trop fort.

An early German mafter thows us a pointer and a wolf-hound in Plate 6.

We do not recommend as models of beauty the two monfters (Plate 7) taken out of the Directorium Humane Vitce (1480), but very likely they were drawn from a crofs-breeding between the greyhound and maftiff. Bergman von Holpe, in the firft edition of the Stultifera 
Navis (1494), has drawn a lion-dog (Plate 8, No. I); while greyhounds are reprefented by Ant. Sorg, in AEfop's Fables (Augrburg, I 475); and Fuft and Schœffer, in the illuminated of the famous Pfalter of 1457 (Plate 8, Nos. 2 and 3). The drawings of Plate 9 are taken from the firft edition of the Ship of Fools, and thow bullterriers and two dogs licking the fores of the poor pilgrim at the door of the rich man.

In Plates Io and I I are the varieties of dogs feen, or more likely imagined, by the artift who illuftrated the curious book of Fables compiled by Sebaftian Brandt, and printed at Bafle by Jacobus de Phortzheim in $150 \mathrm{I}$. Has Mich. Wohlgemuth, the mafter of Albert Dürer, drawn from nature this fingular crofs-breeding between maftiff and greyhound, with his lion-tail (Plate 12, No. 2), in the Nuremberg Cbronicle, I 493? More faithful to nature, perhaps, but very little artiftic, are thofe reprefented by Wynkyn de Worde in the far-famed St. Alban's Book of Fuliana Barnes (1496). Ifrael van Meckenen, the early Dutch or German mafter (1482-1489), has reprefented in his curious engravings (Plates I 3 and I4) greyhounds, French poodles, fox-hounds, cur-dogs, fpaniels, fetters, \&c. Albert Dürer (147I-I528) reprefents bloodhounds (Plate I5), greyhounds (Plate I7), lion-dogs, poodles, and Scotch terriers (Plate I 8), a boar-hound, and, perhaps, a Newfoundland, in his engraving of the Knight followed by Death (Plate 19).

John van Eyck's terrier (Plate I6) is drawn from the picture in the National Gallery, London. In the book of the Toifon d'Or, by Guillaume de St. Bertin (Paris, 154I, in folio), is, perhaps, what we may call a King Charles (Plate 20, No. 1) ; while No. 2 are, perhaps, boarhounds, taken from the Difcours du Songe de Polipbile (Paris, I 54 I). 
Lucas Cranach (1470-I 553) reprefented (Plate 21) fpaniels, and a favage-looking wolf-dog. The dogs of Lucas van Leyden (I5I6, Plate 22) Thow the bull-dog, the pointer, the fetter, and an Italian greyhound. Burgkmair (Plate 23), in the triumph of Maximilian, depicted a lion-dog and a fpaniel, very much like a Newfoundland. In Plate 24 are a harrier and a black and tan terrier, by Robetta, I 520 ; a bloodhound by Montagna.

Urs Graf, or the mafter known alfo by the name of Gamperlein, introduced many dogs in his Pafion, printed by Knoblouch, Strafburg, 1507 (Plates 25 and 26). Martin de Vos (1 579-1 586) reprefented (Plate 27) greyhounds, fpaniels, King Charles's, \&c. But the firft appearance of dogs, beautifully drawn, in an Englifh book, may be traced to George Turberville's Noble Arte of Venerie, or Hunting, London, 1576 (Plate 28), in which is a maftiff bitch with her pups, a black or Swifs fox-hound (Plate 29); harriers, retrievers, a maftiff dog (Plate 30); in the frontifpiece of the book, here reproduced in fac-fimile, a whole pack of fox-hounds (Plate 31). Londerzeel (1 586) Shows a water-fpaniel; and Mair (I 5O I) Scotch terriers. Among German mafters, Hans Shaeuflein (Plate 32) reprefented a wolf-hound, a fetter.

Why R. Pynfon introduced a bear-baiting, feveral times reproduced, in the Antiboficon (London, I $52 \mathrm{I}$, in 4to.), is eafy to guefs in the hatred which even grammatical difputes were able to produce in the pure fcholaftic era. The poor bear is affailed here (Plate 33) by a hoft of maftiffs, and perhaps of bull-dogs, which the artift has not very faithfully reprefented.

Early Italian artifts defigned few dogs in their works. One of the large wolf-hounds of Nicoletti da Modena (1 536, Plate 4) is reprefented 
with the muzzle now and then impofed on dogs in France by the police authorities, when they fuppofe the temperature fufceptible of engendering hydrophobia - a miftake which often caufes a hetacomb of innocent canine victims.

Joft Ammon, in his very curious book on hunting, entitled, Kunfliche wohlgeriffene neu Figuren von allerlai fagt Kunft. F. furt am Mayn (1 592, 4to.), has drawn almoft all the known varieties of fporting dogs (Plates 35-42). The dog (Plate 43, No I) with his tongue after the heraldic fafhion, illuftrates the title of Sir. Thomas Cockaine's Short Treatife of Hunting (London, 3591, in 4to.), which may be confidered as the ftarting-point of fox-hunting as fince practifed in England. The three drawings Plate 43 , No. I, and Plate 44 , are taken from a very curious little book of drawings printed at Lyons by Jean de Tournes, in 1556 (8vo.), without any text, but which had been ufed formerly by him in his printed books.

In Plates 45 and 46 are the dogs drawn by Boiffard, and fo beautifully engraved by Theodor de Bry. The following Plate (47) has drawings by Beckerweld (1626). Plate 48 is a fac-fimile of the title-page of The Difcovery of Witches, in Anfwer to Several Queries lately delivered to the Fudges of AJize for the county of Norfolk (London, 1647, 4to.), by Matthew Hopkins, to whom Butler alludes in his Hudibras, p. ii. canto 3 . This Hopkins' fecret to difcover a witch was to throw the fufpected old woman in the water. If the could fwim and fave herfelf of a watery grave, the was fure to be burnt as a witch; if drowned, the was confidered innocent of the heinous crime of witchcraft. Some relations of the numerous victims of Hopkins imagined that Hopkins could not difcover the witches unlefs himfelf a wizard. In confequence, they 
refolved to fubject him to the water's trial, and as he could not fwim and was drowned, they concluded he was, after all, a very poor wizard. Although Hopkins' imps are rather fantaftical, dogs have been feen very like them, if their devilifh appendages are taken away.

From a curious print of the time is taken (Plate 49) a butcher's dog, as known in 1652 . The print accompanies the life of Hind, the great robber, and pretends to reprefent him when he was a butcher's boy. The dogs (Plates 50 and $5 \mathrm{I}$ ) engraved by W. Faithorne, are drawn from the illuftrations of the Englifh tranflation of Homer, by John Ogilby. (London, 1660, in folio). The laft, but not leaft, drawing (Plate 52 ) is from an engraving by Cornelius van Noorden (1683), in the Print-room of the Britifh Mufeum. 


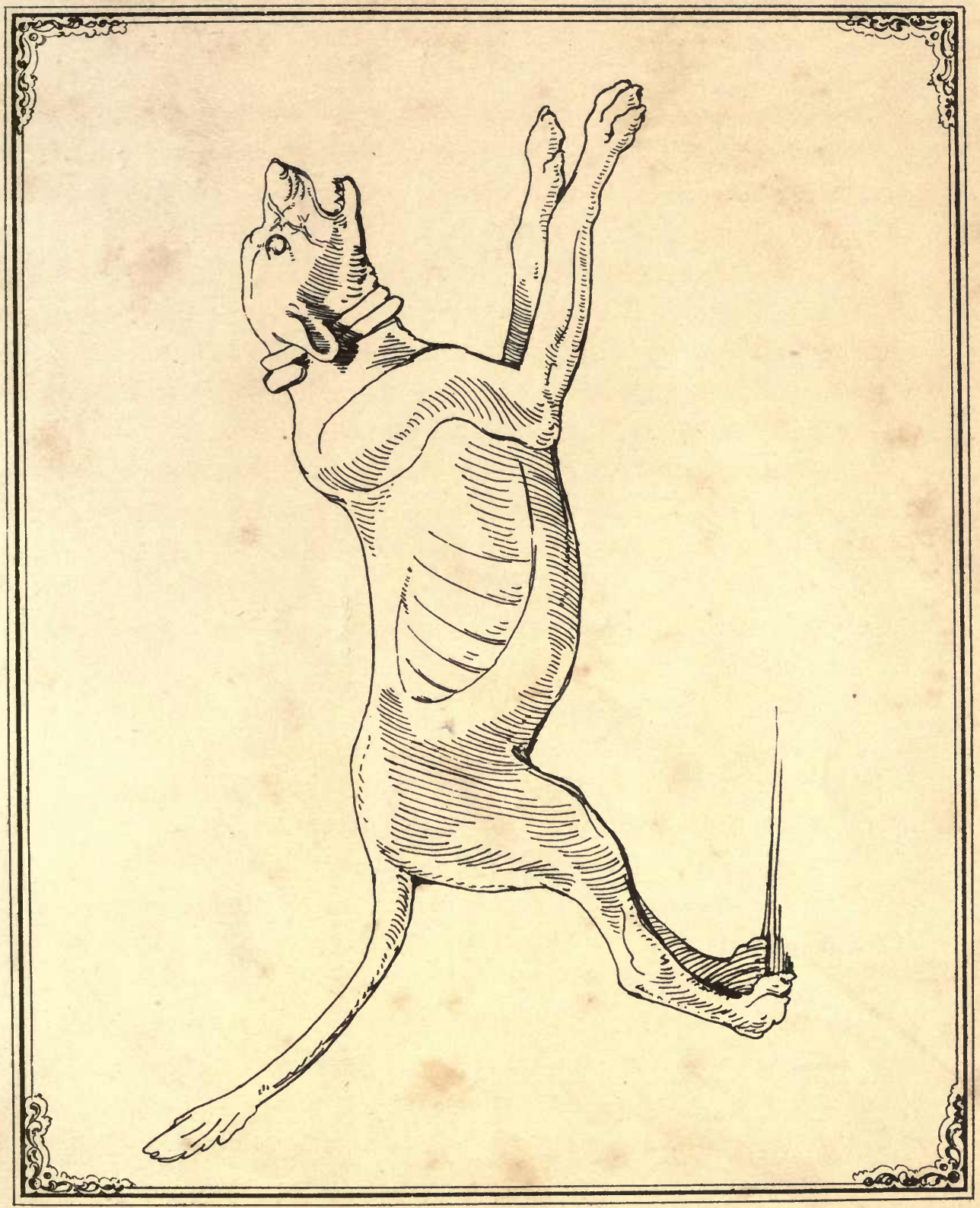





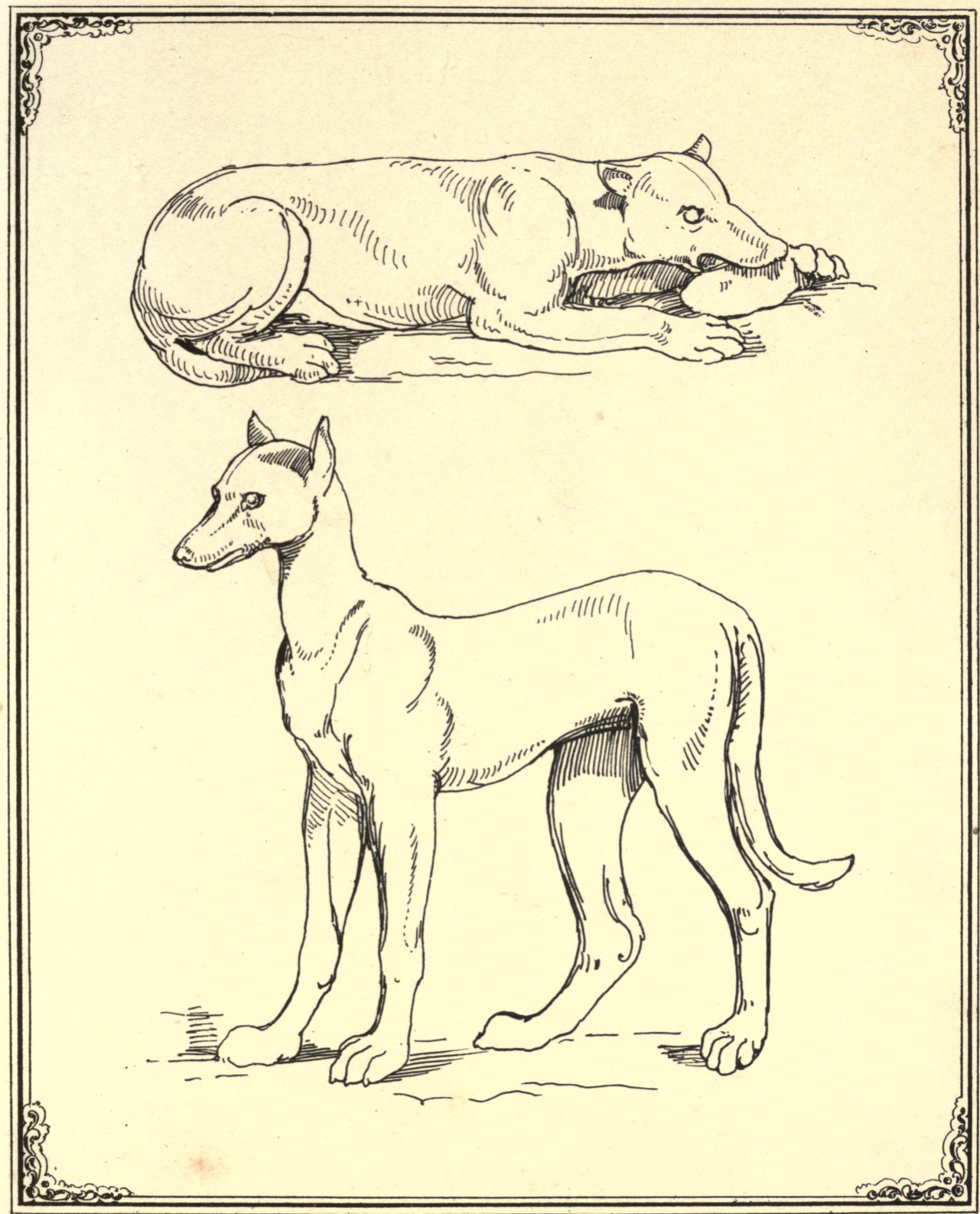

ANTIQUE FROM THE. BRITISH MUSEUM 


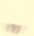




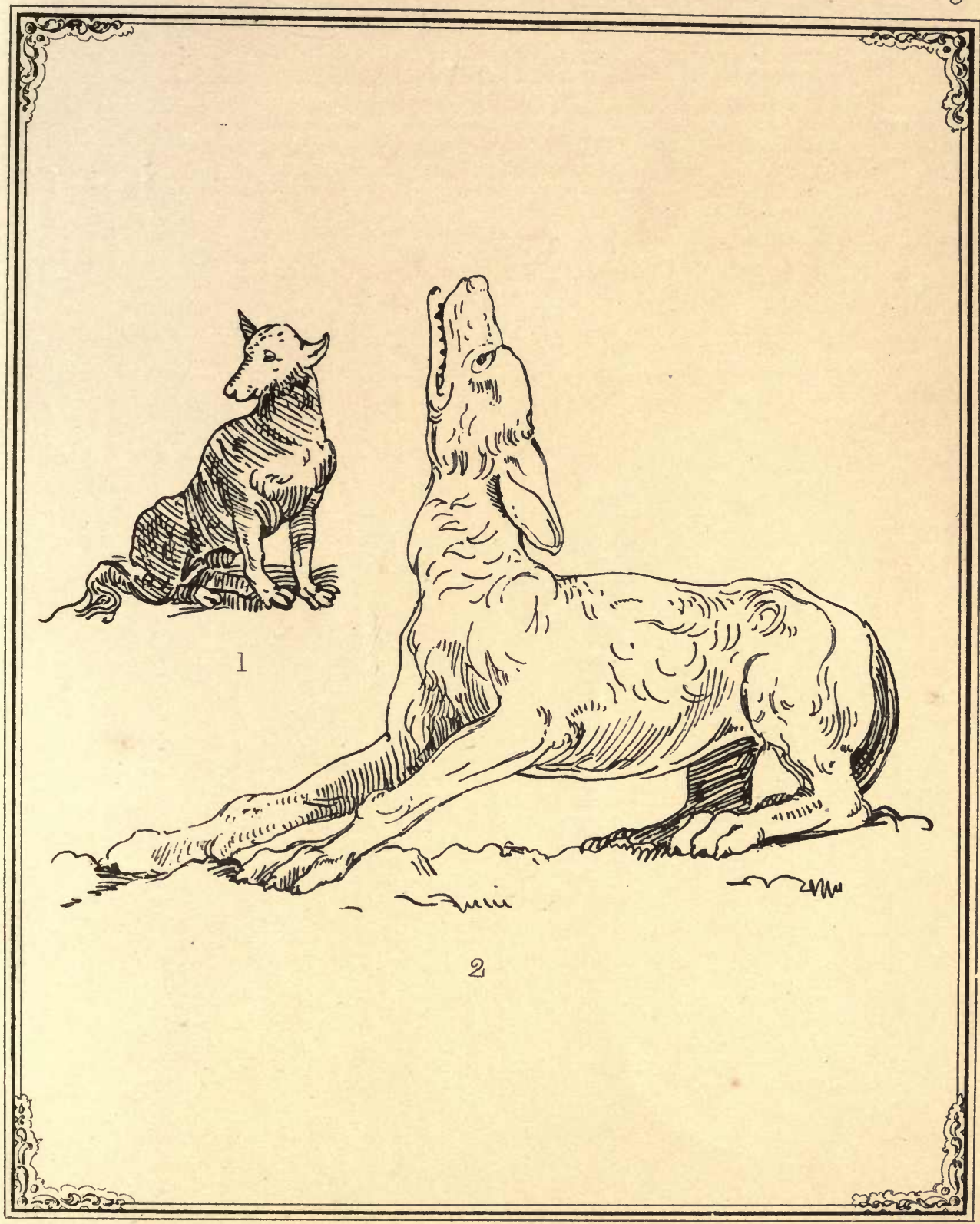

ANTIQUE I MARMI DEL DONI. (2) DO BRITISH MUSEUM. 



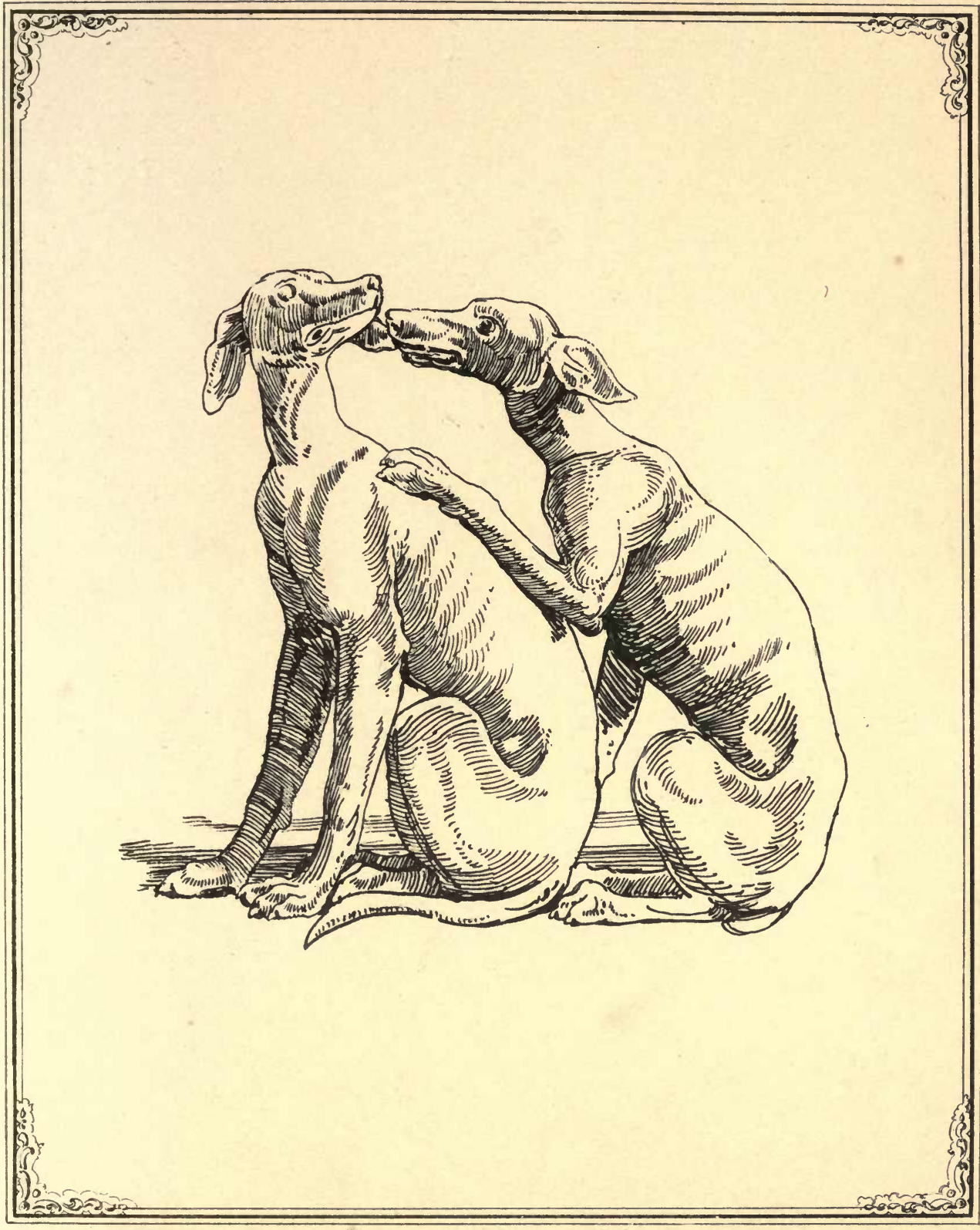





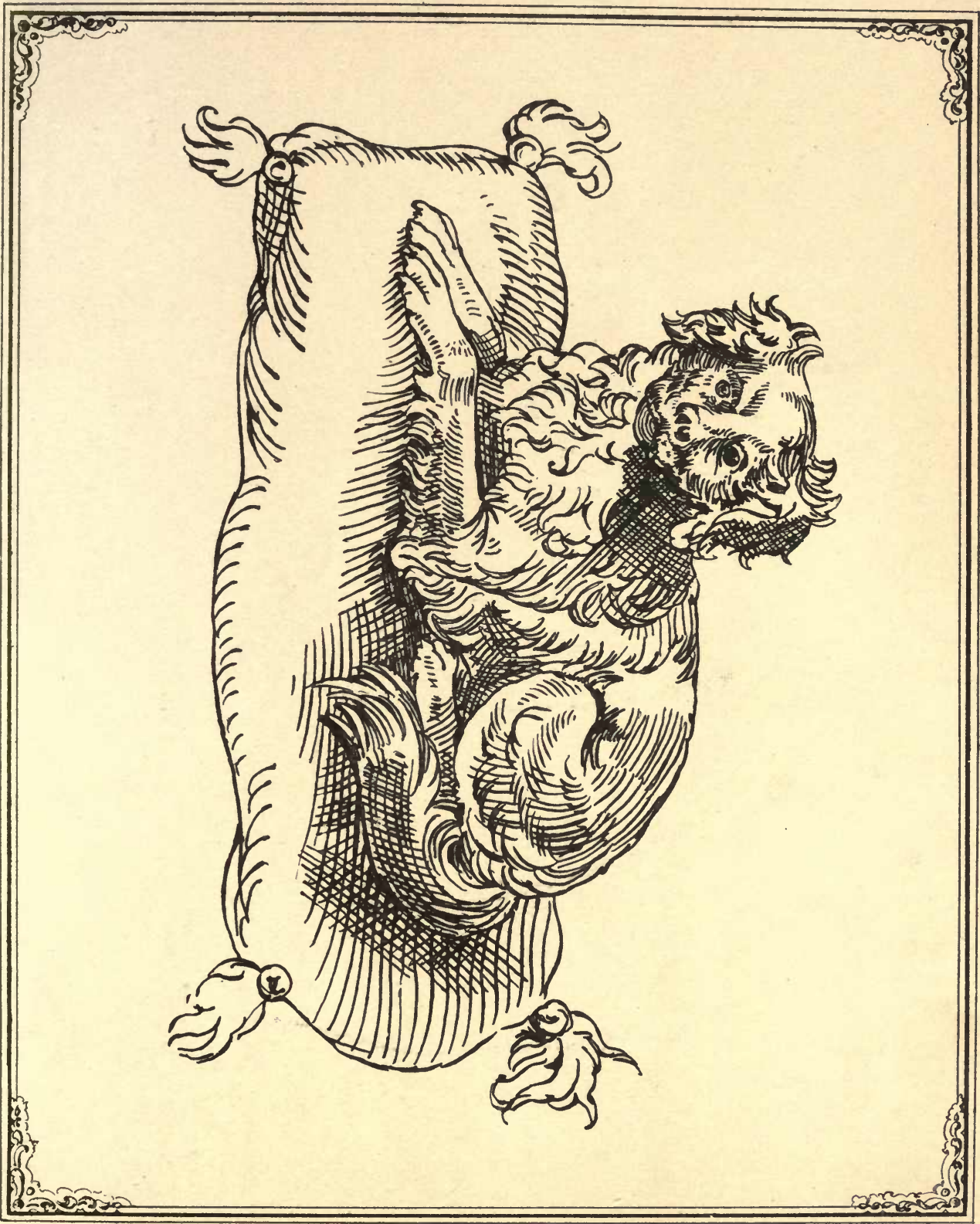





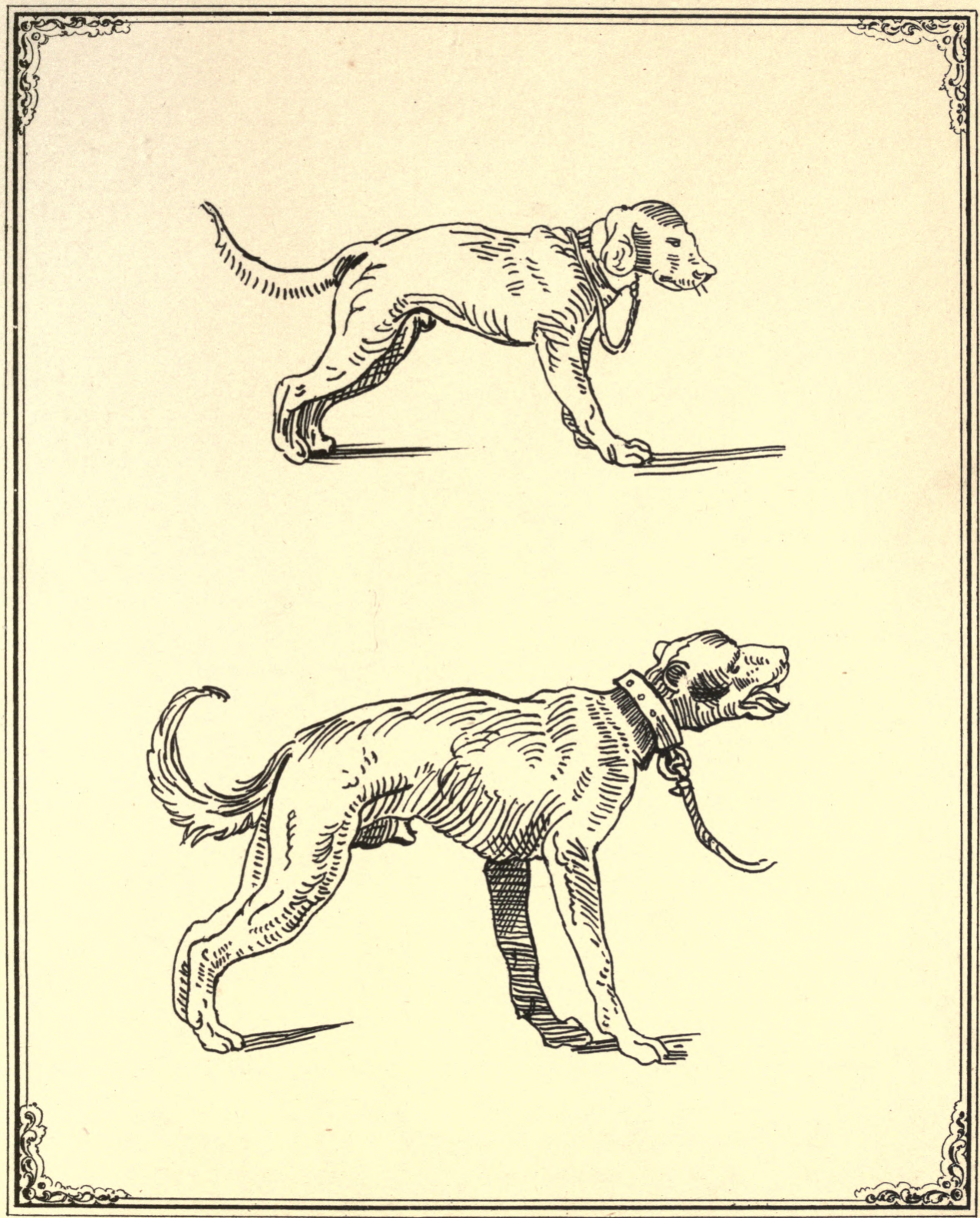




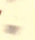




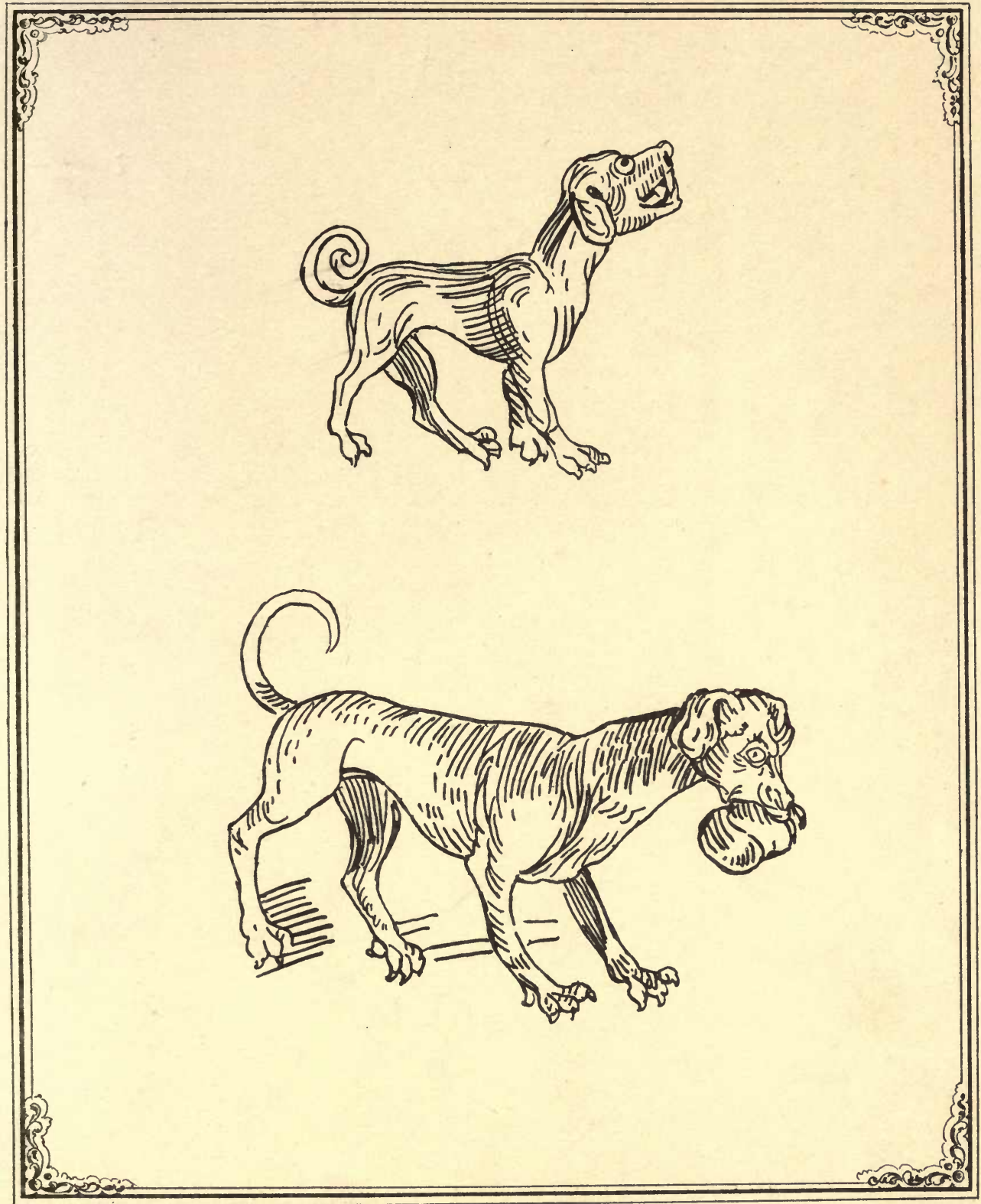





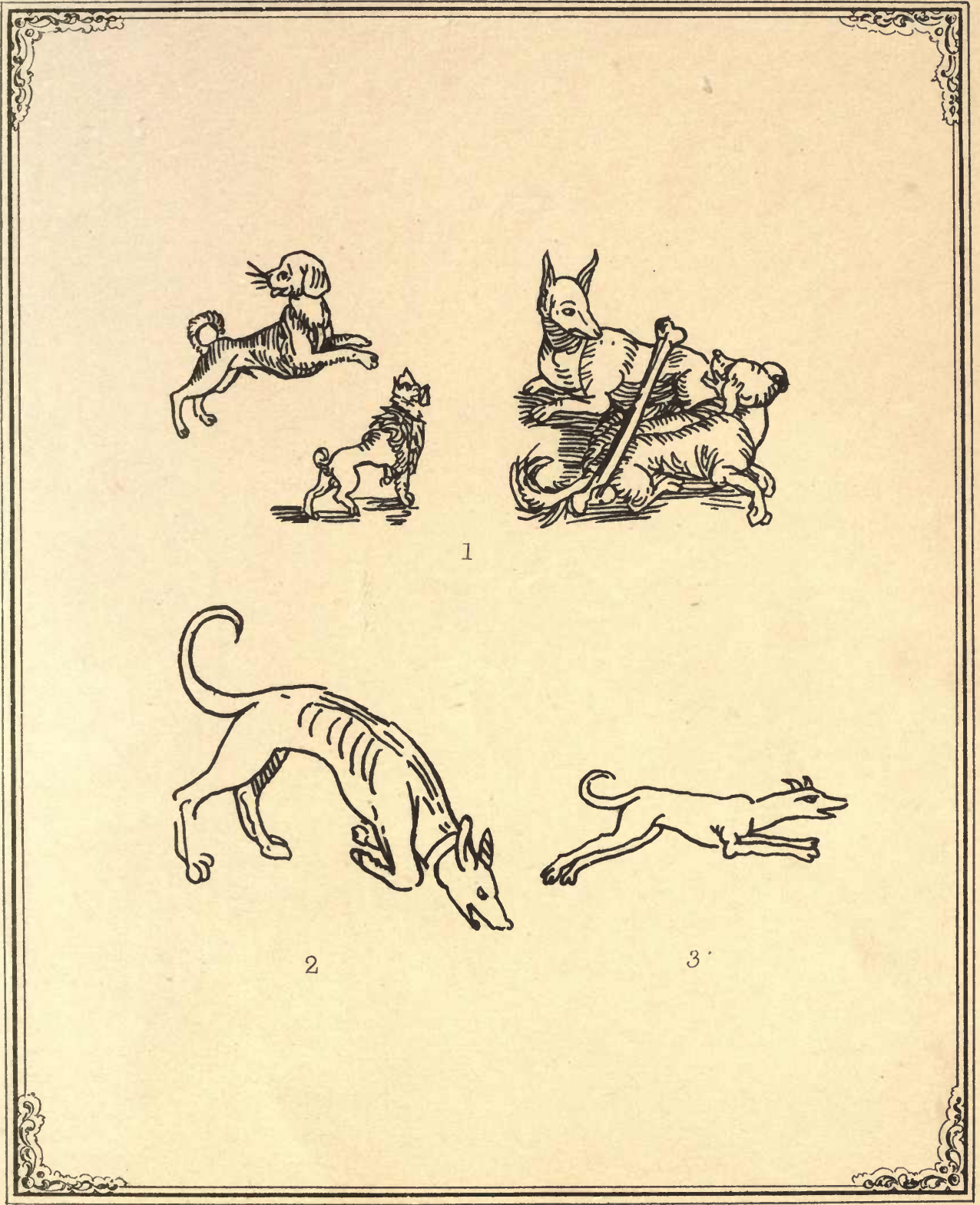

(1) BERGMANN VON OLPE, 1494 (2) ANT SORG, 1475. 



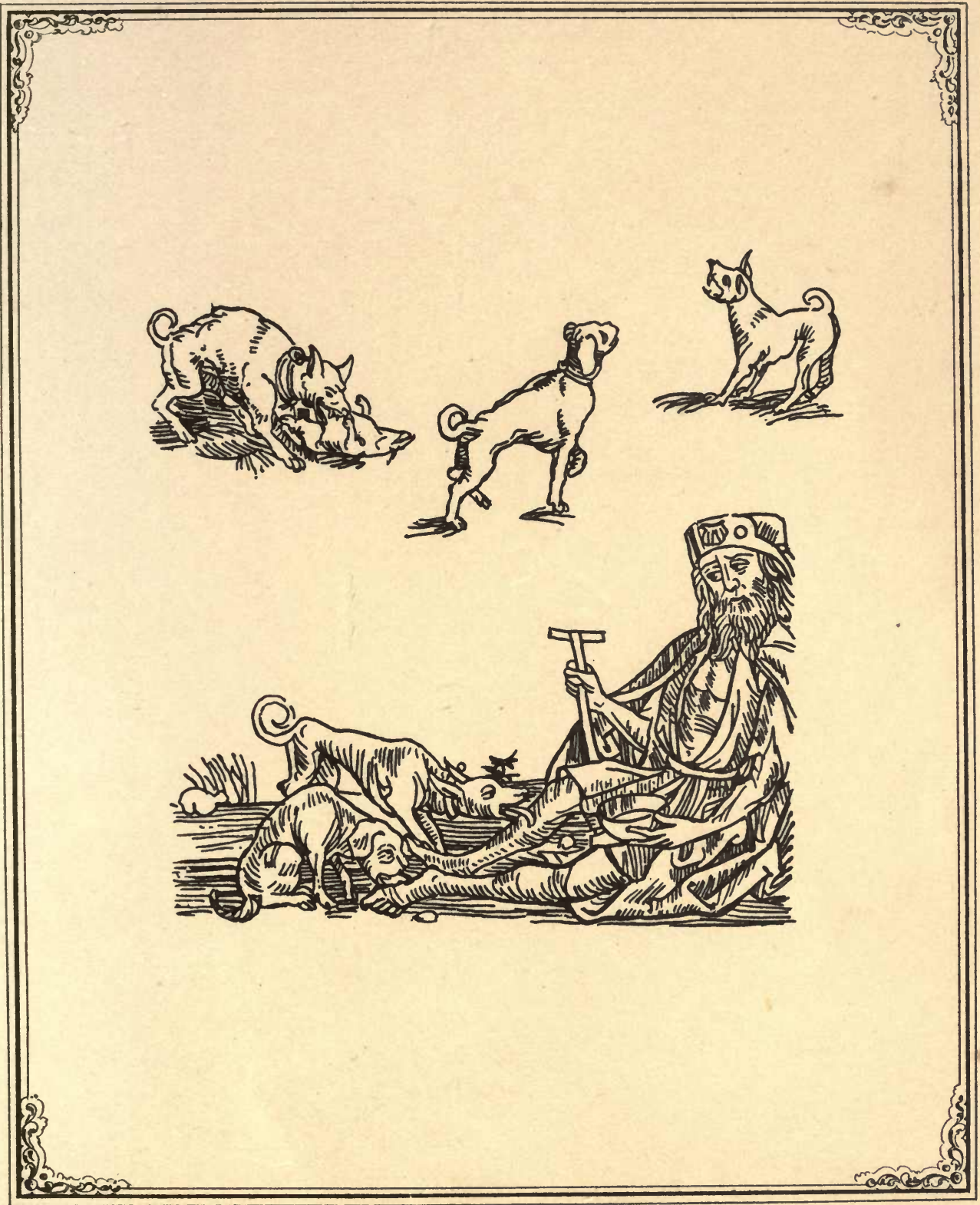

J. B. VON OLPE, 1494. 



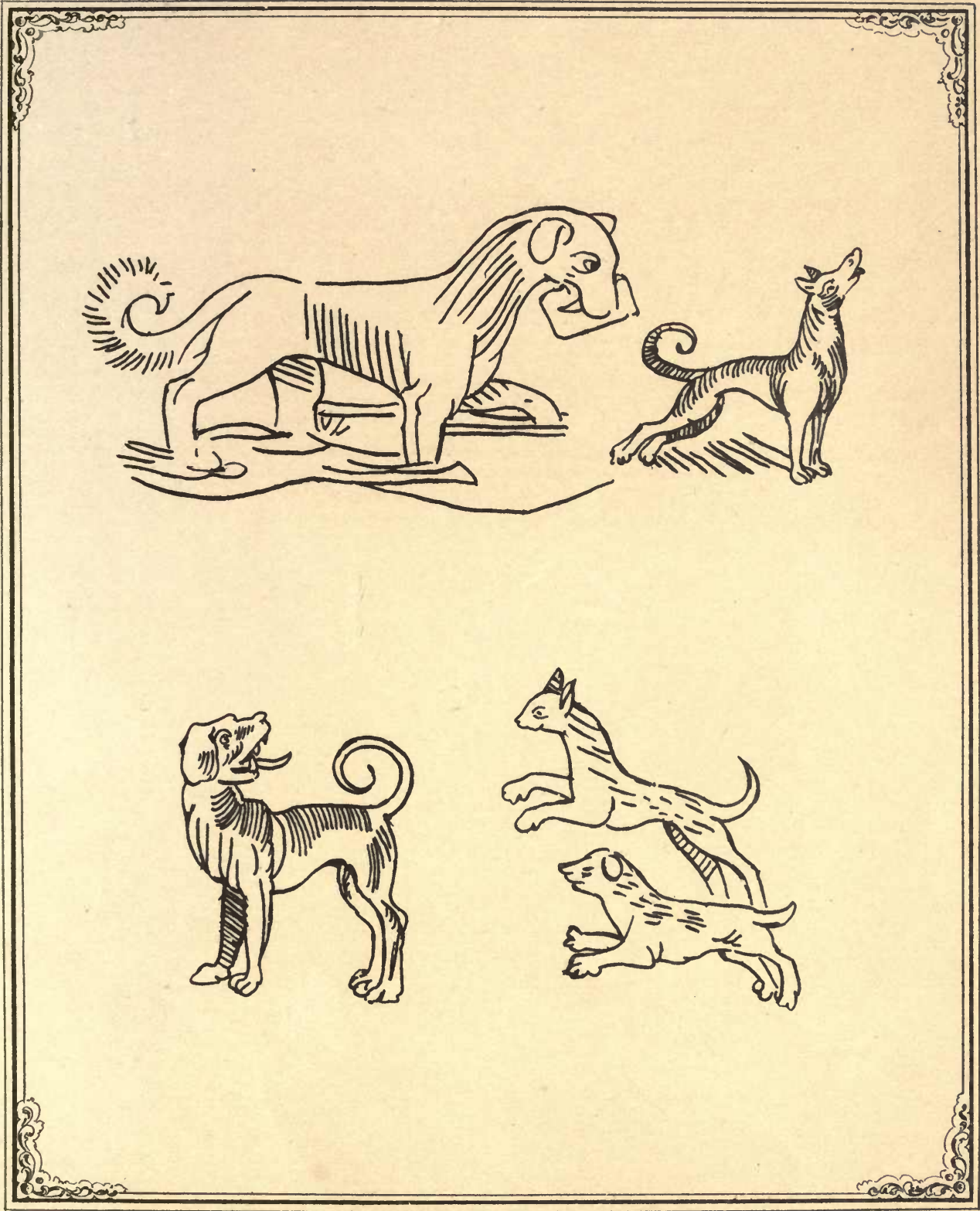


.

프.

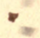




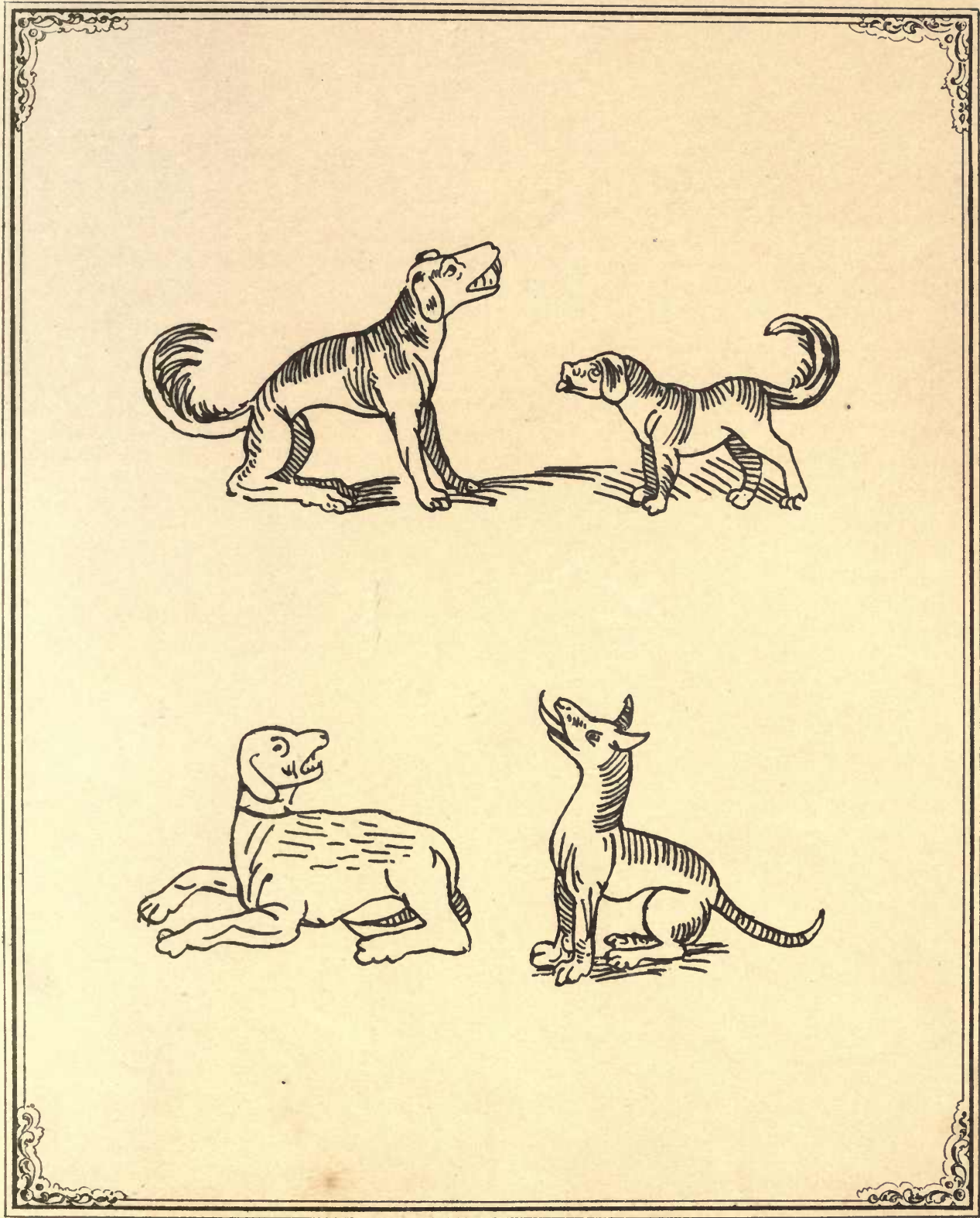





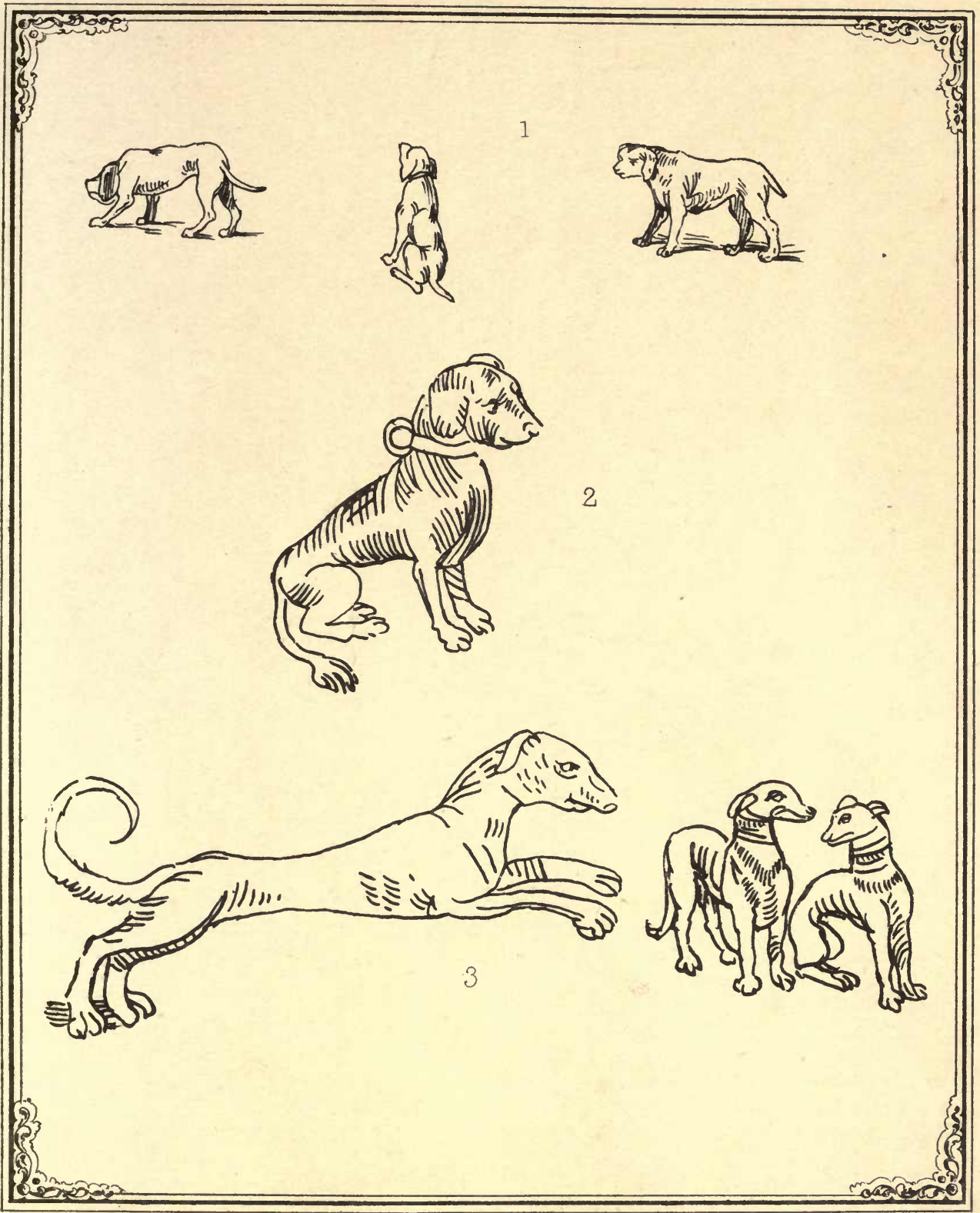

1 FROM A M.S. IN THE BIBLIOTH. ROY. PARIS.

(2) NÜRENBERG GRONICLE, 1493. (3) WYNKYN DE WORDE, 1496. 


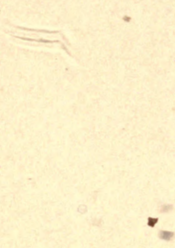

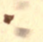




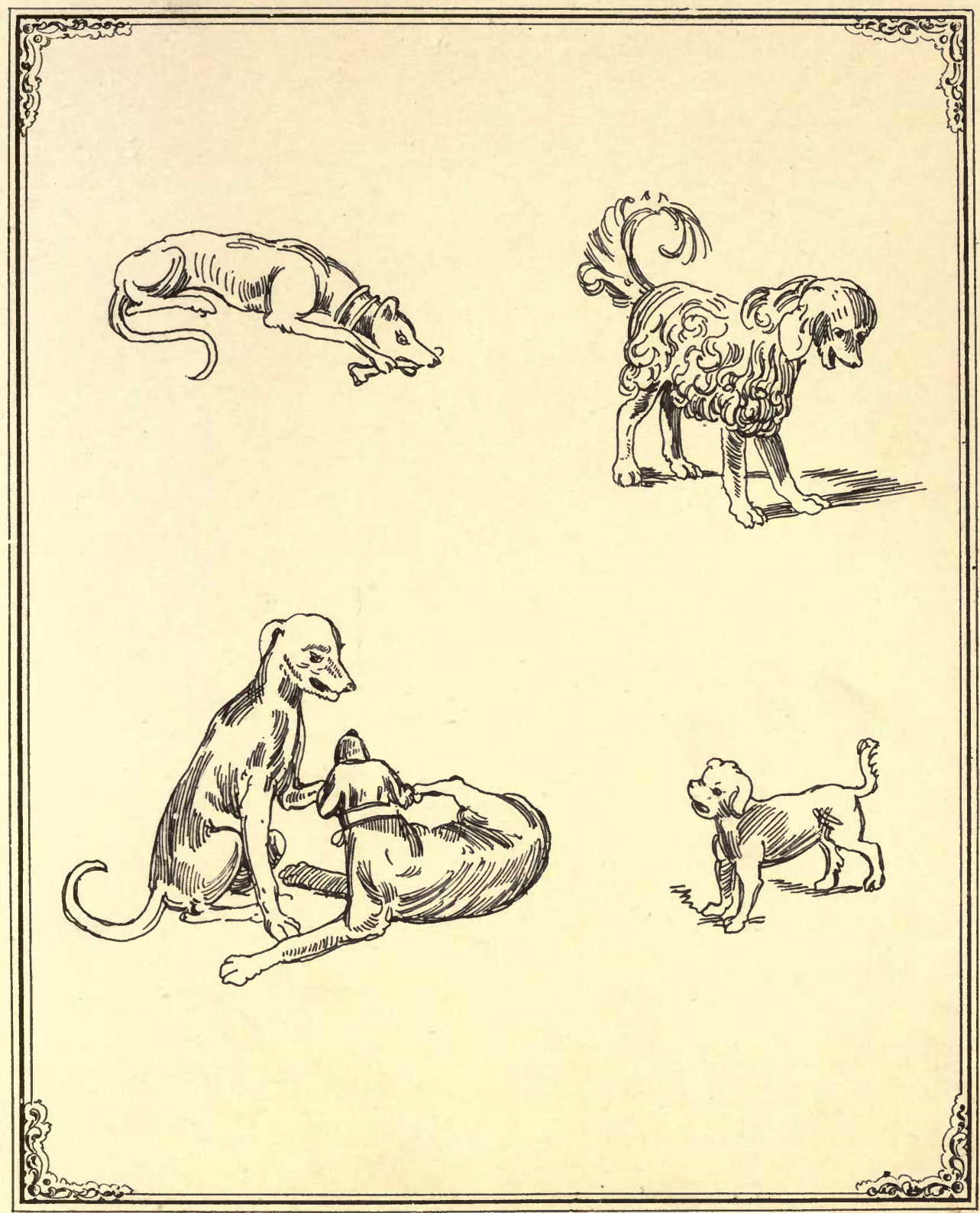





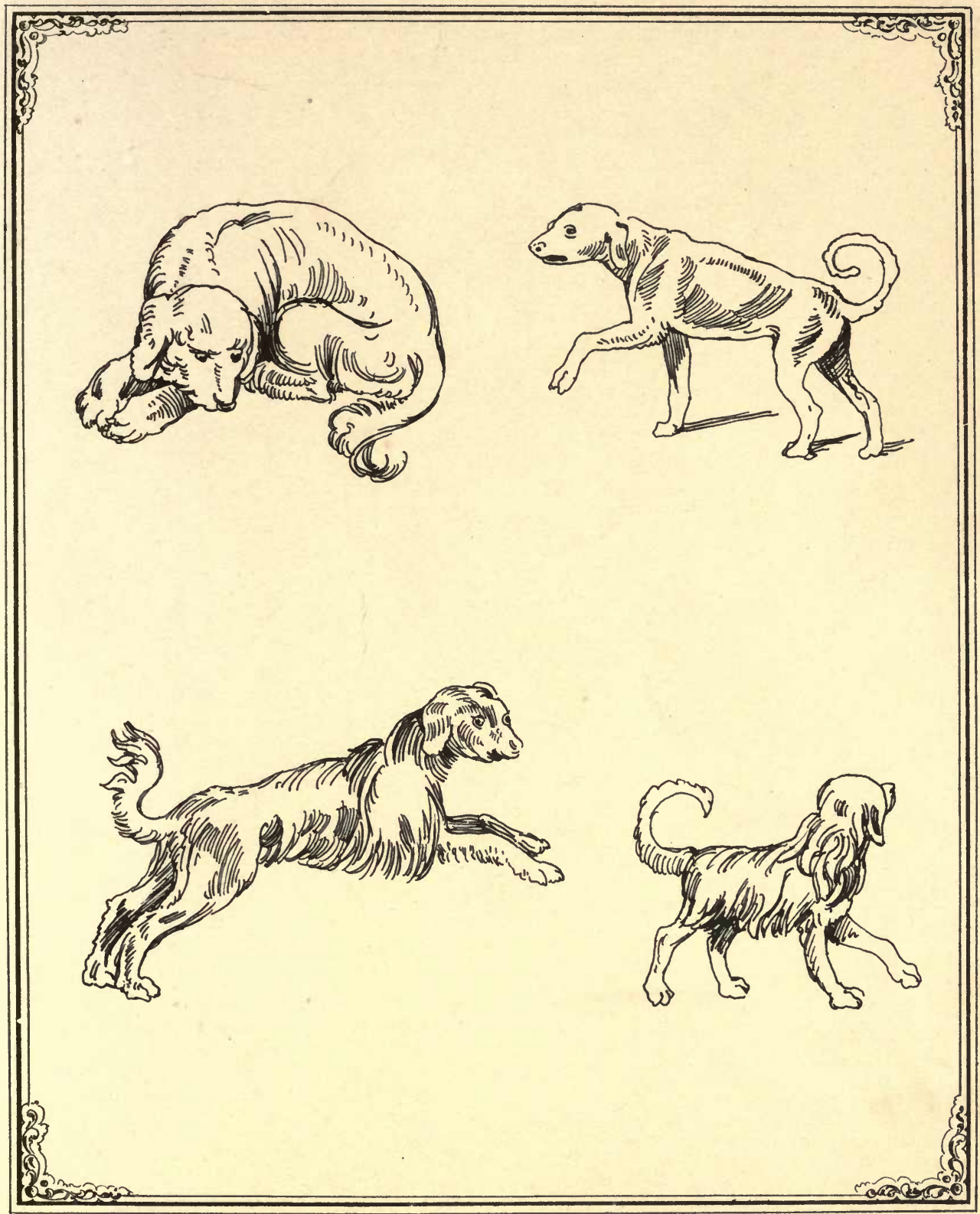





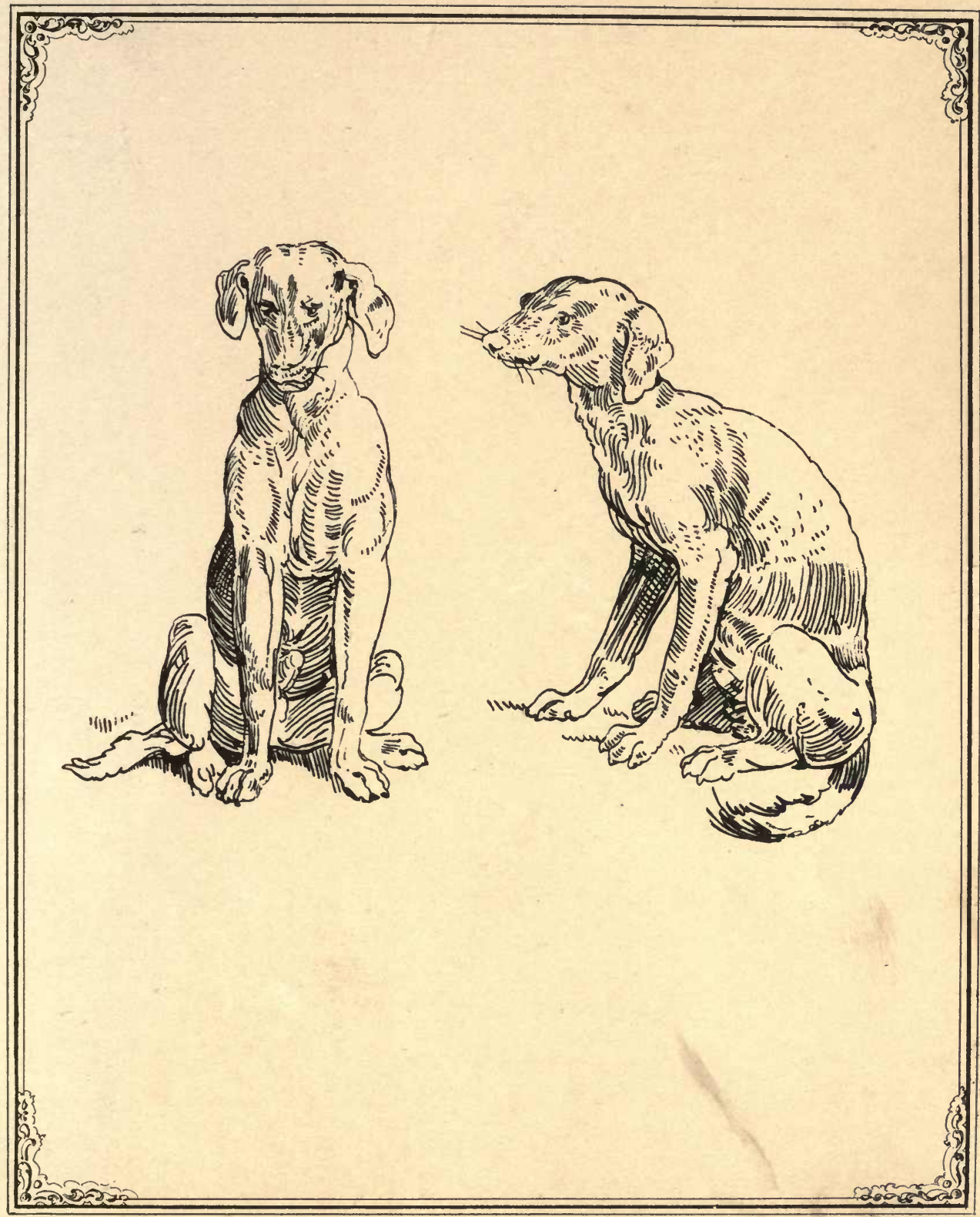





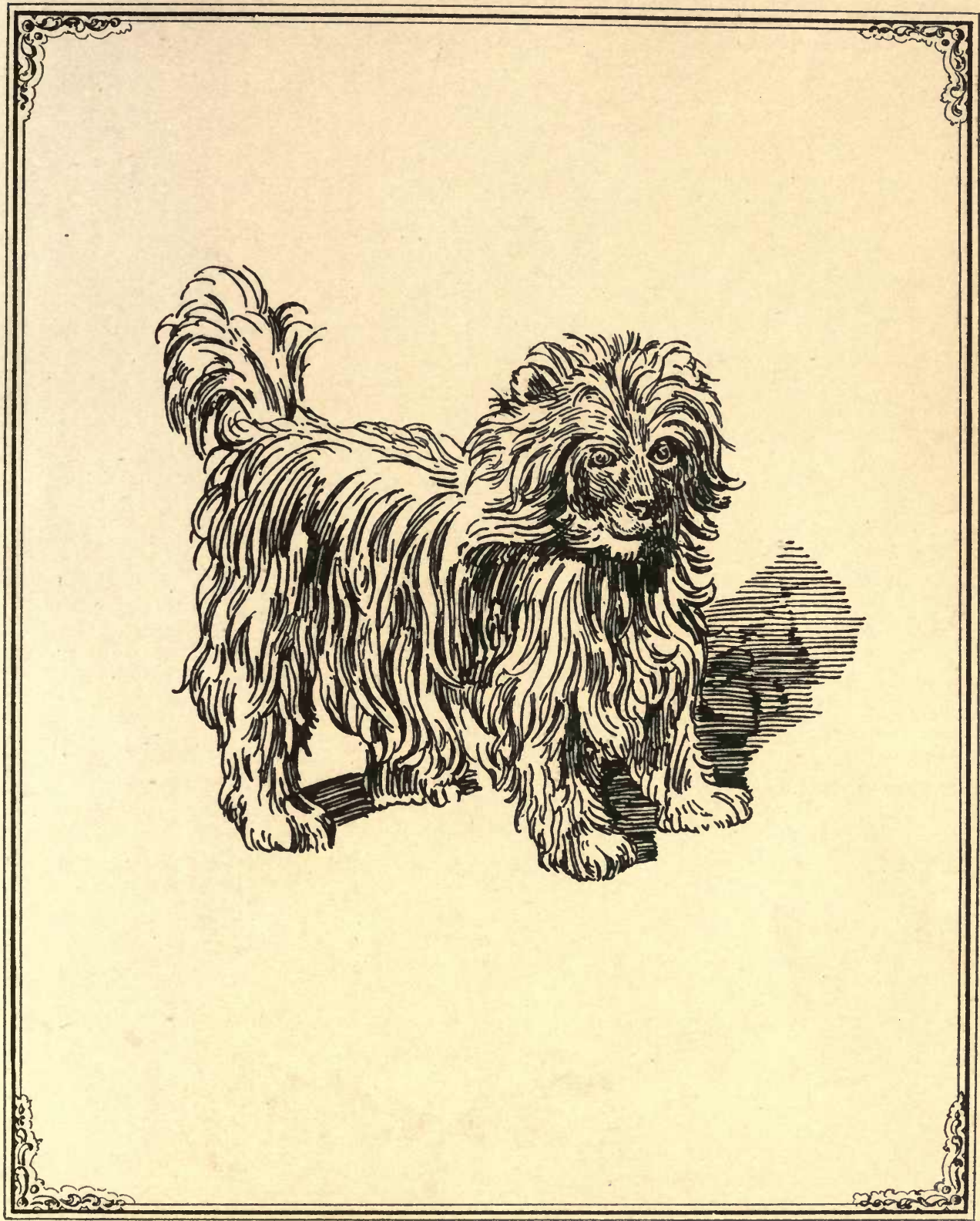


$+2$

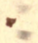

1 


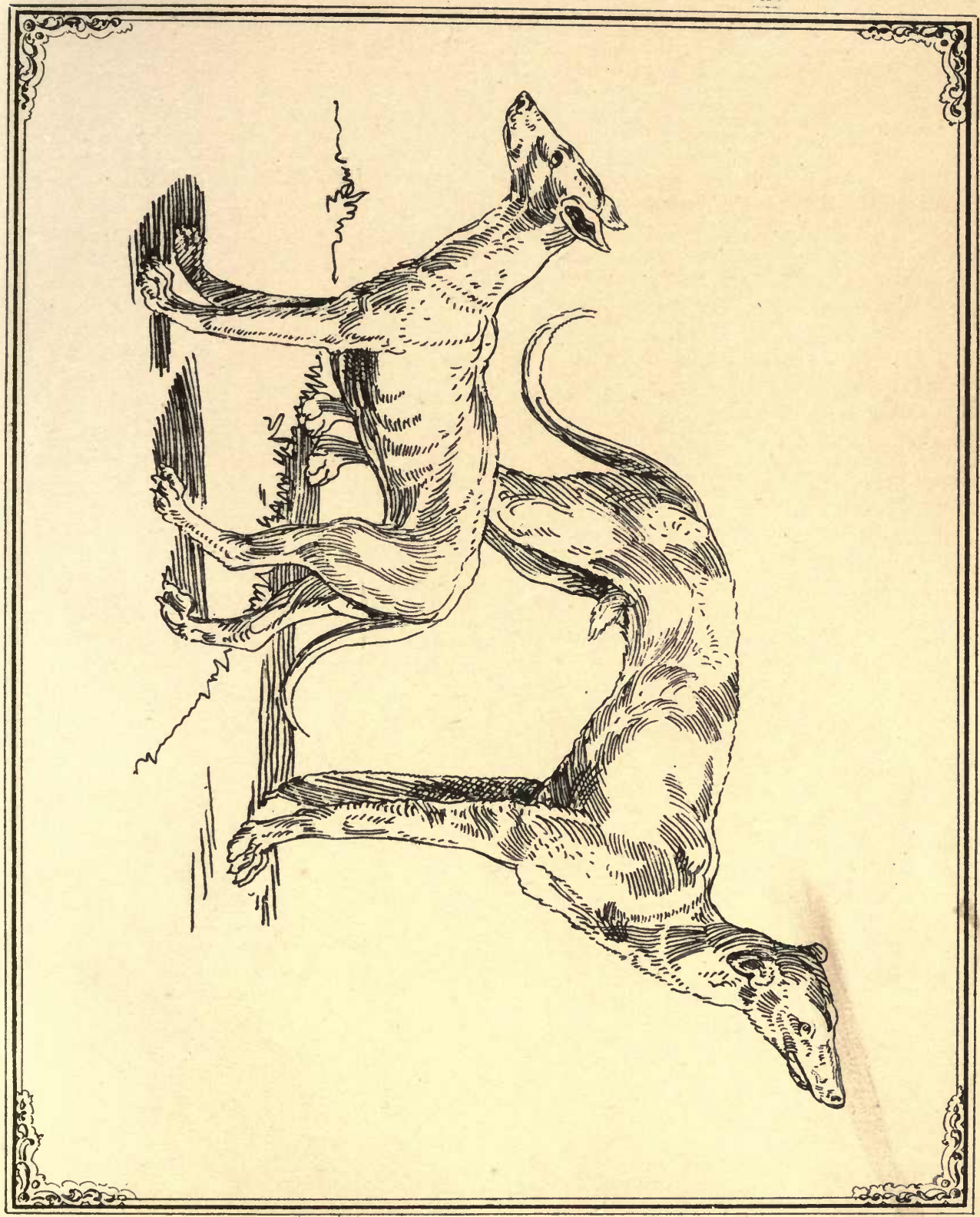

ALBERT DÜRER, $1471-1528$ 



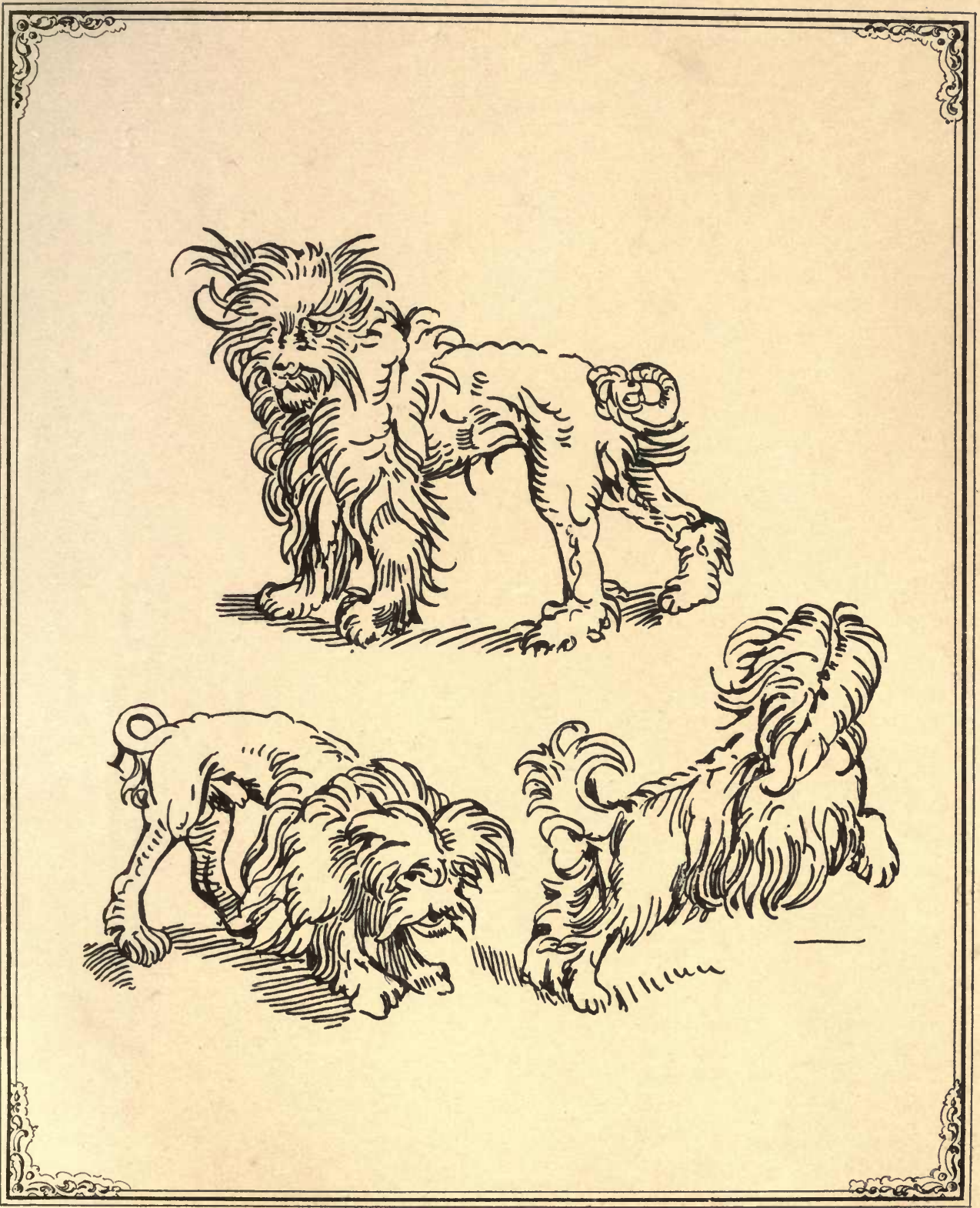





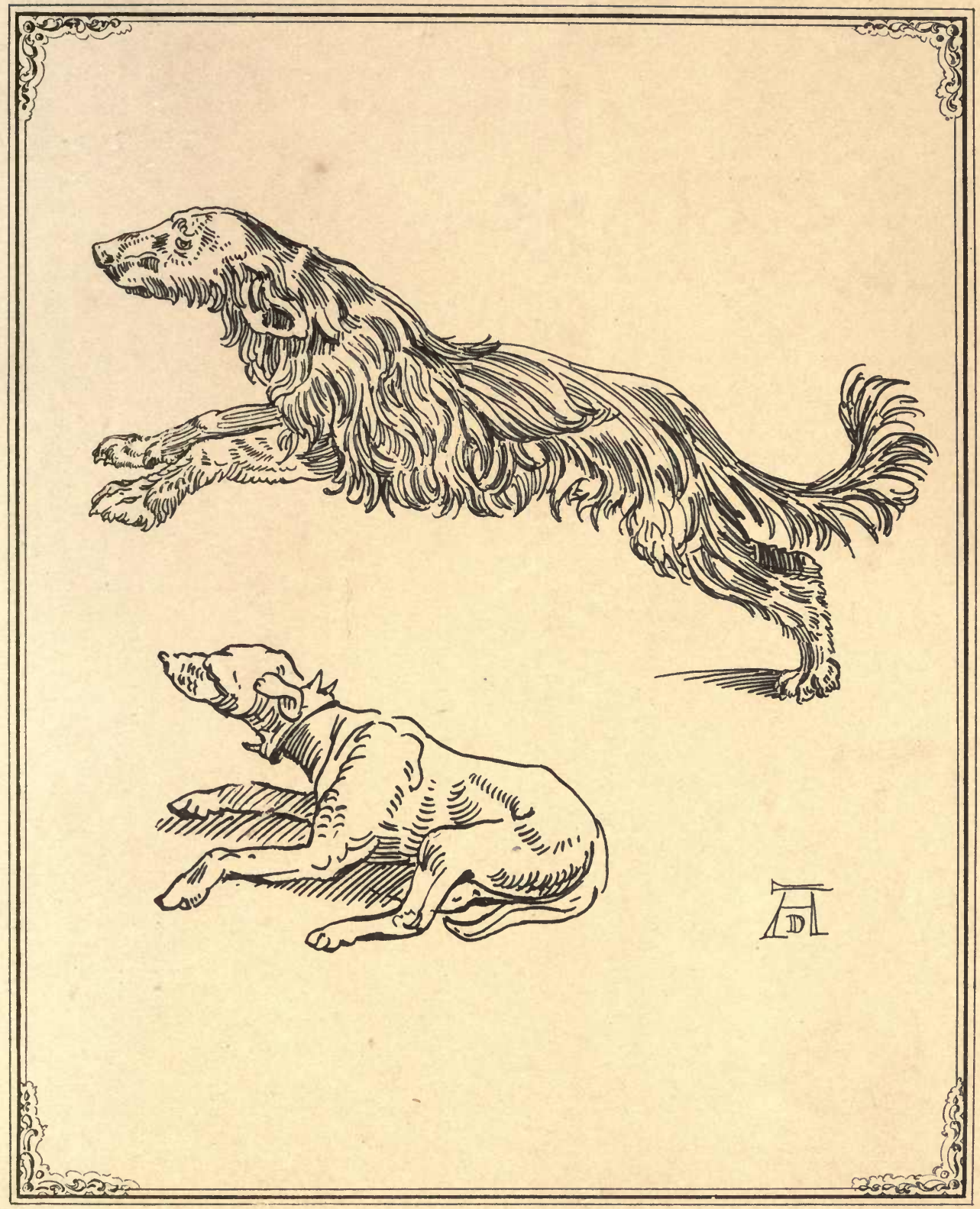





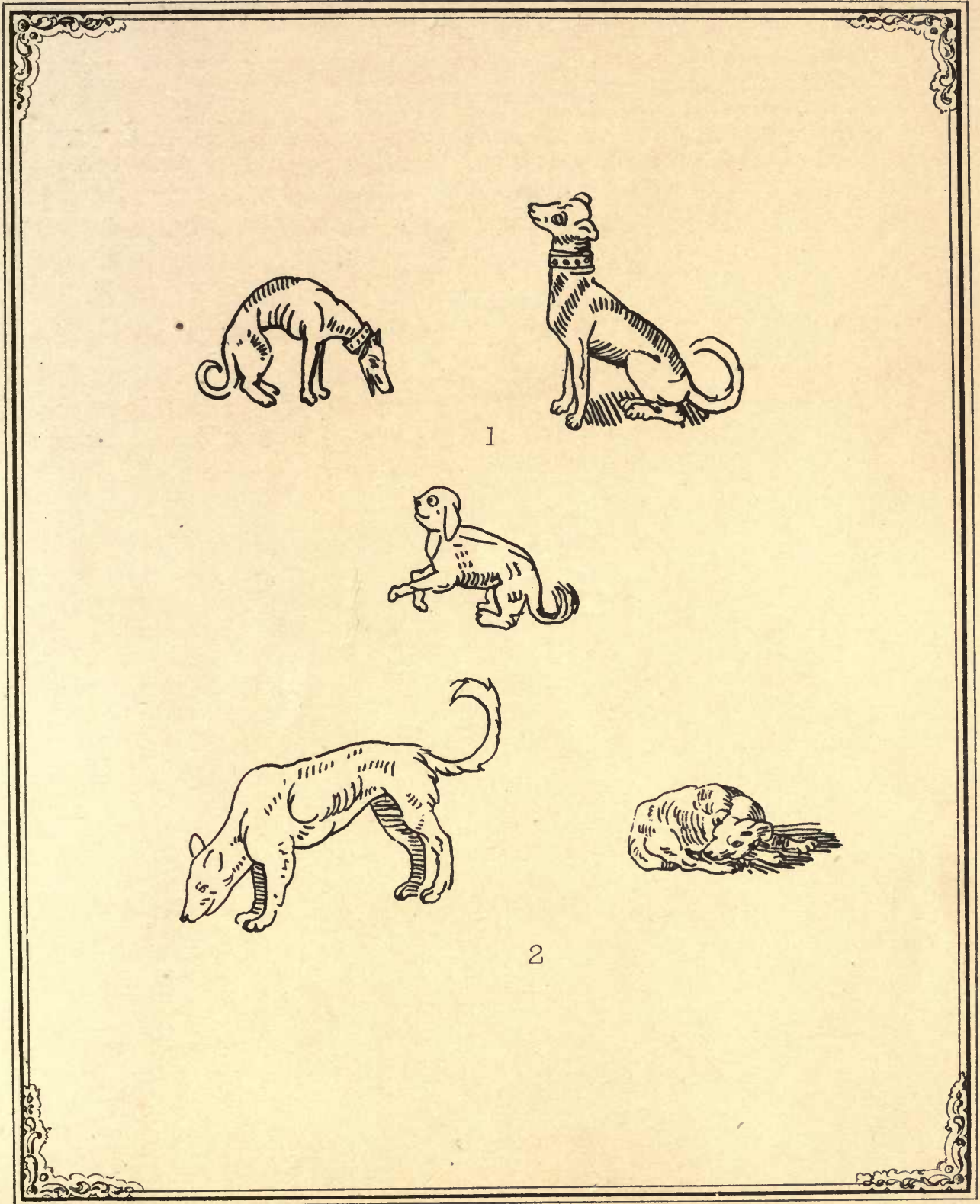

(1) TOISON D'OR, 1541. (2) SONGE DE POLIPHILE, 1541 



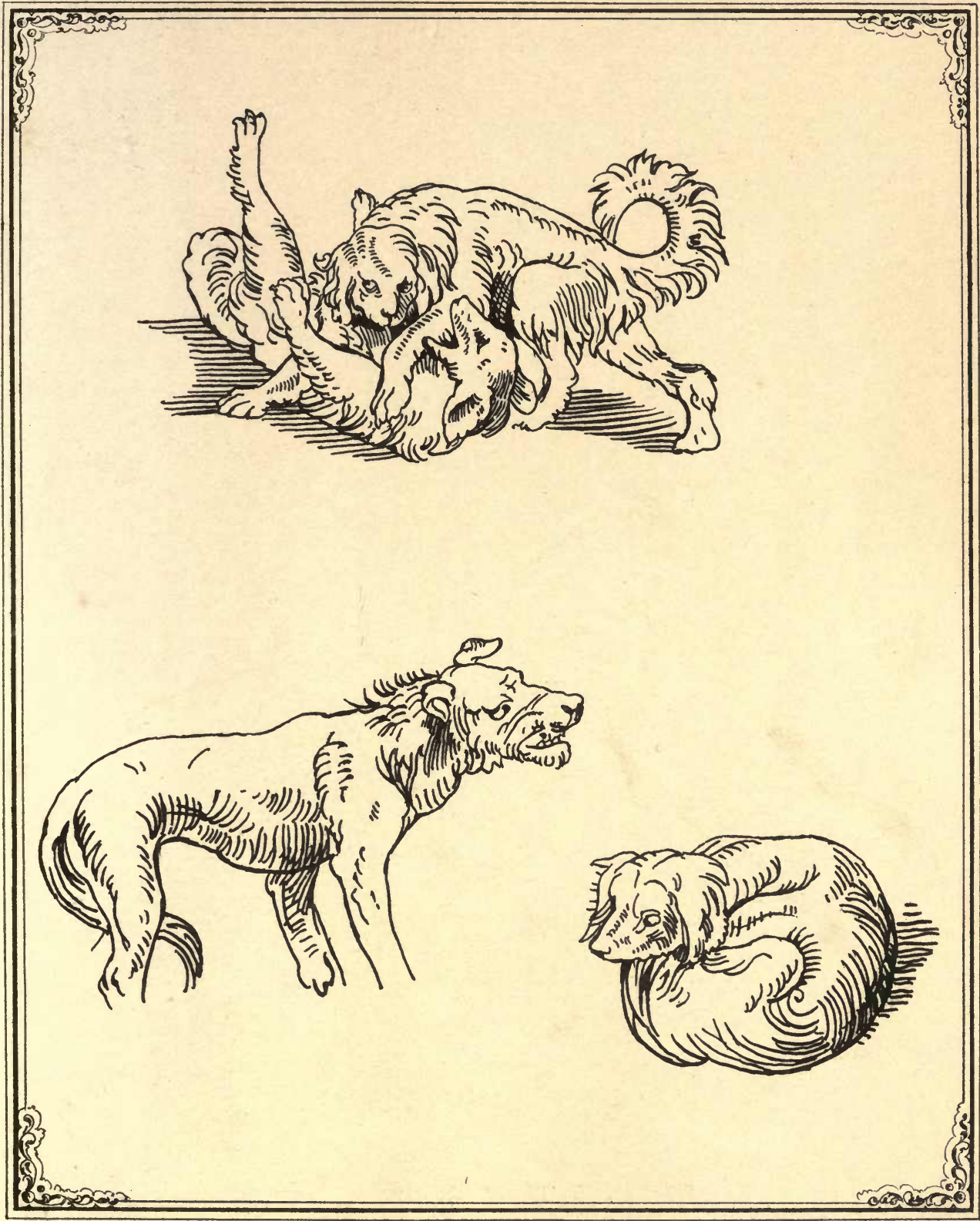





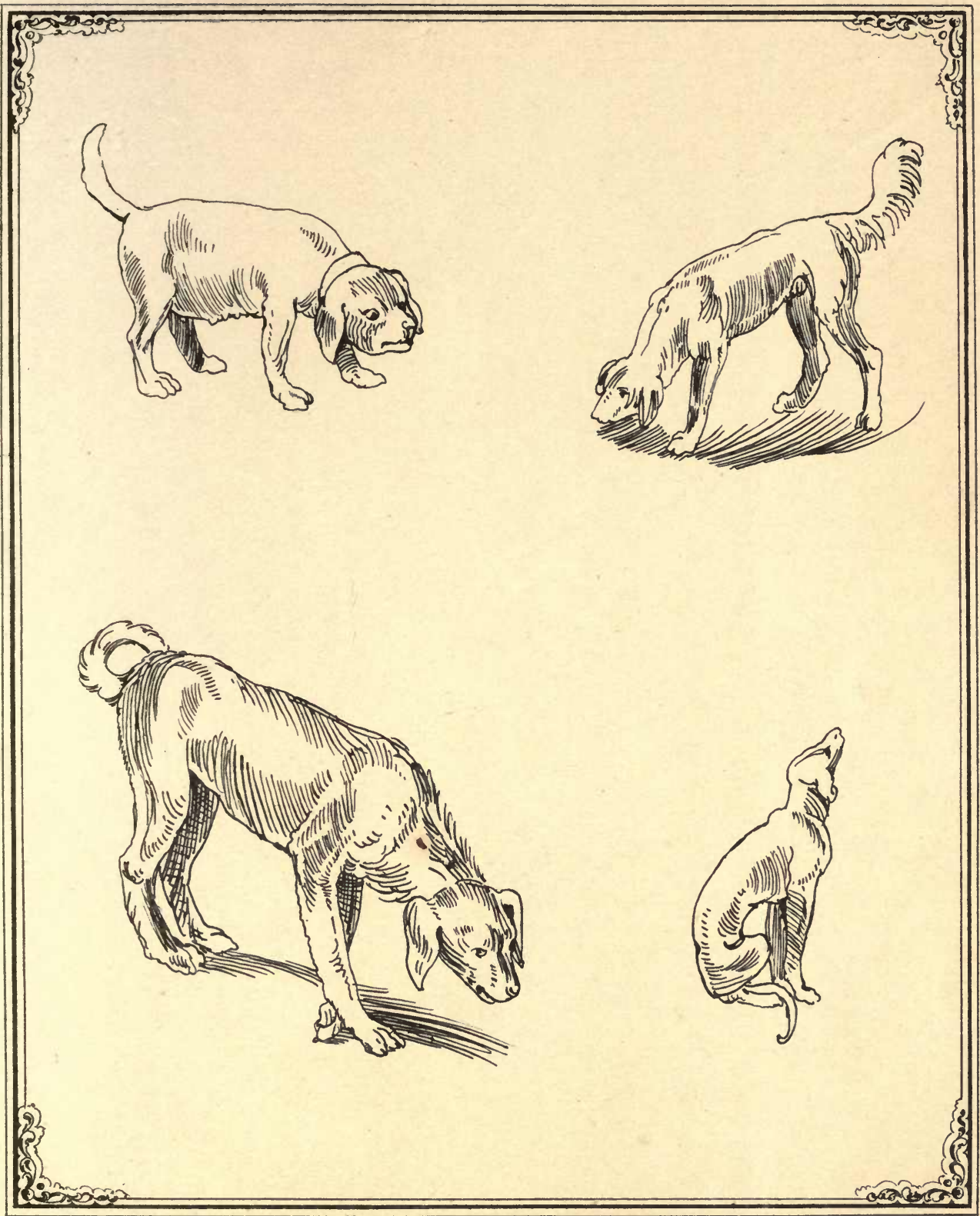





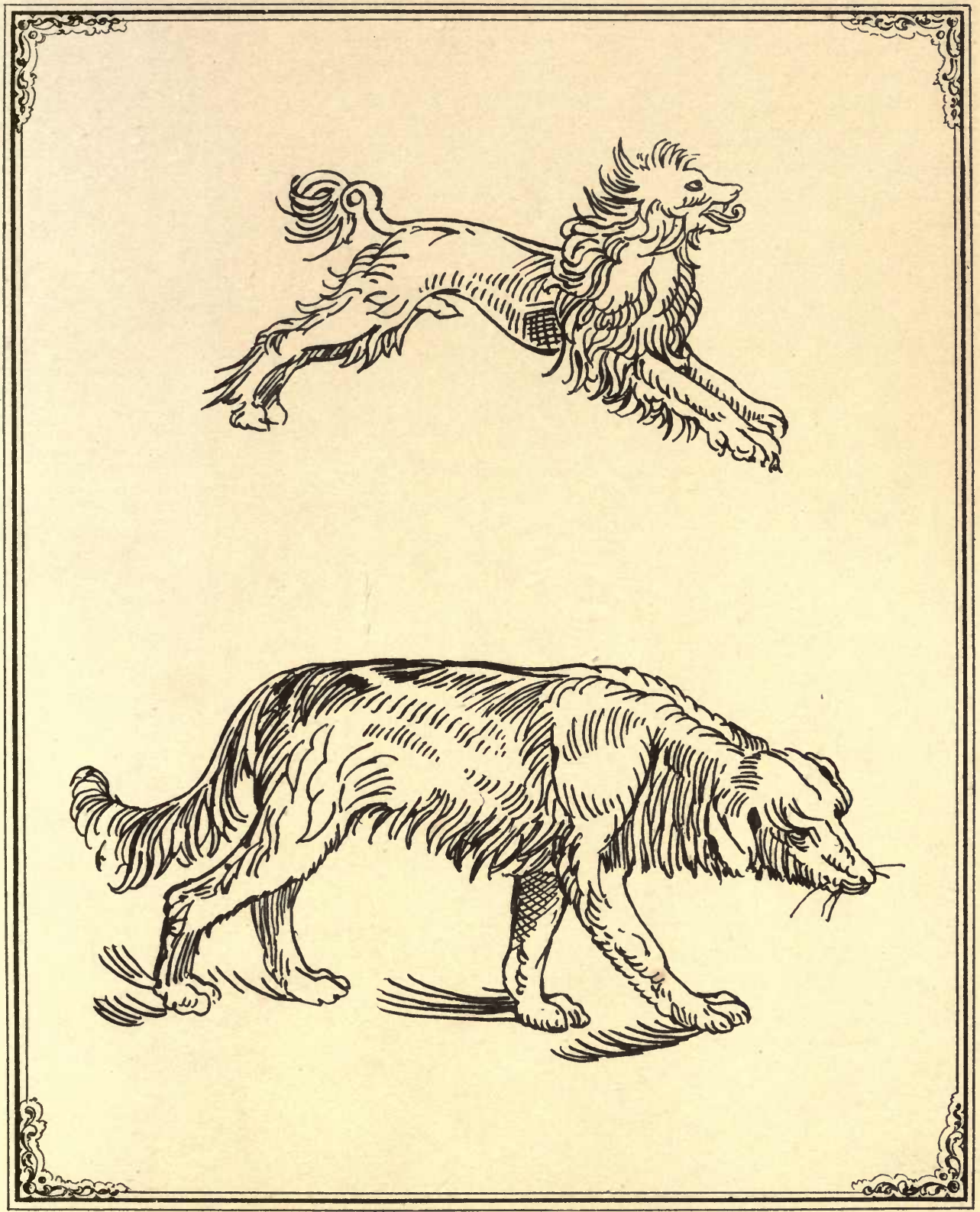





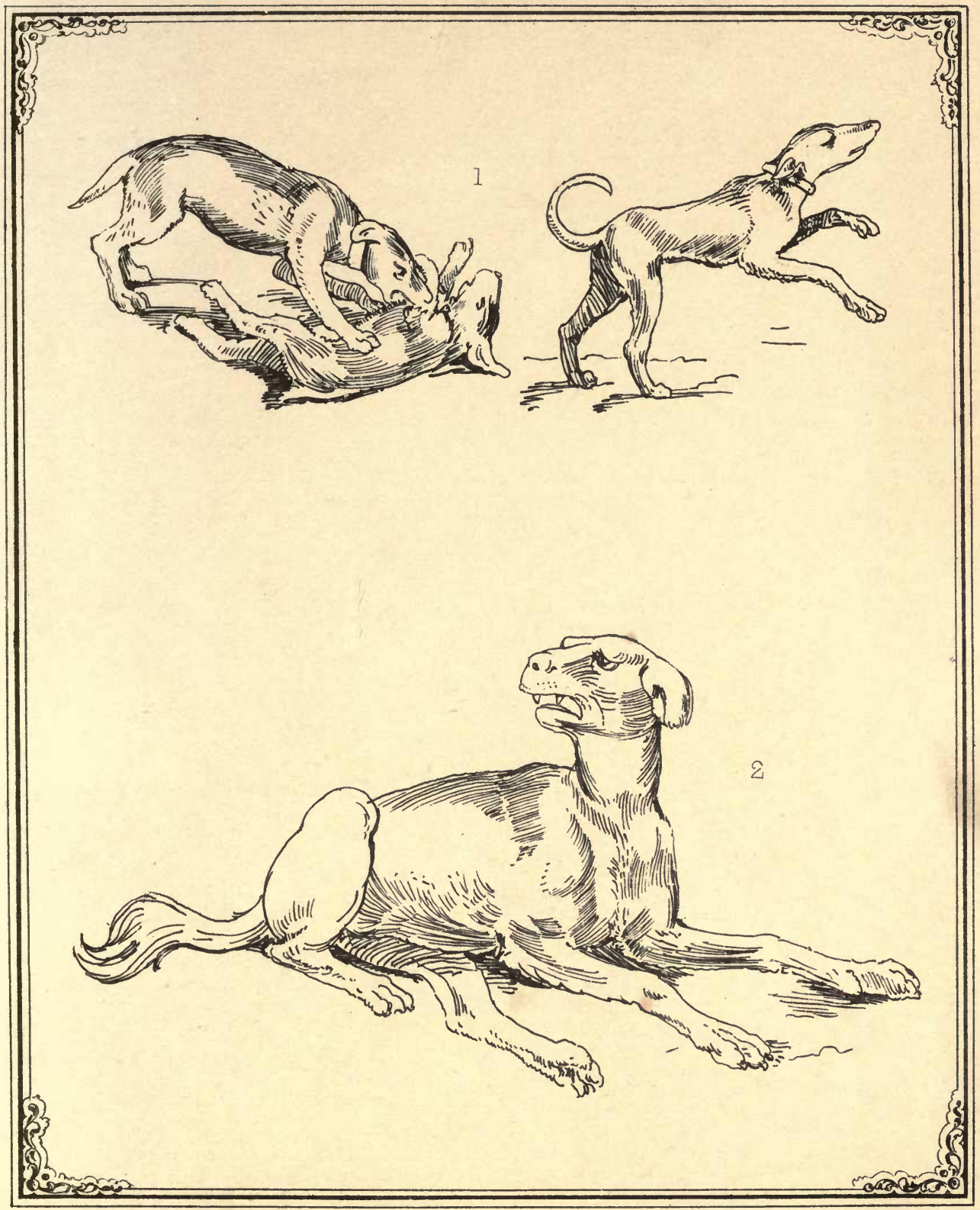

(1) ROBETTA - 1520. (2) BENEDETTÓ MONTAGNA. XVI cr 



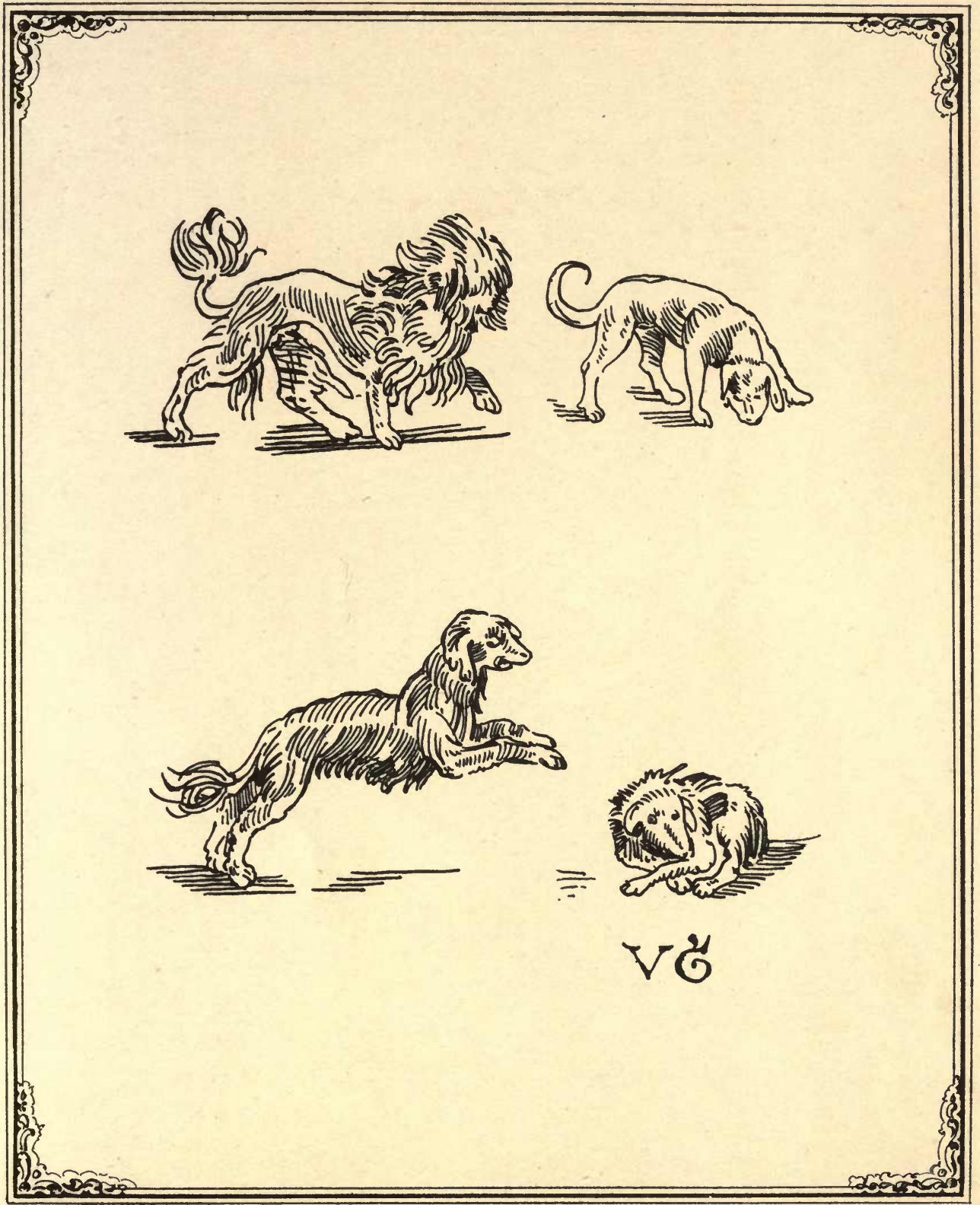





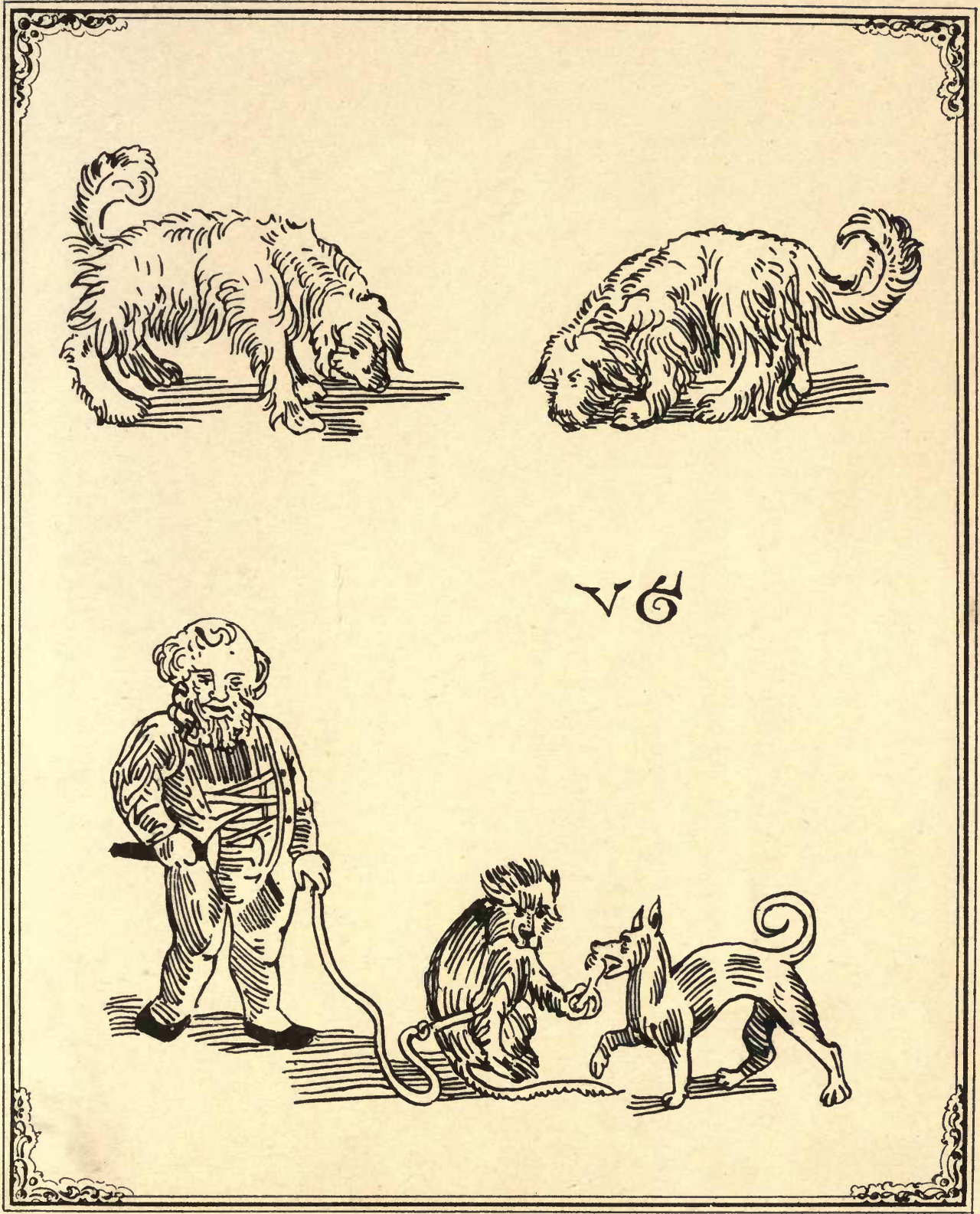





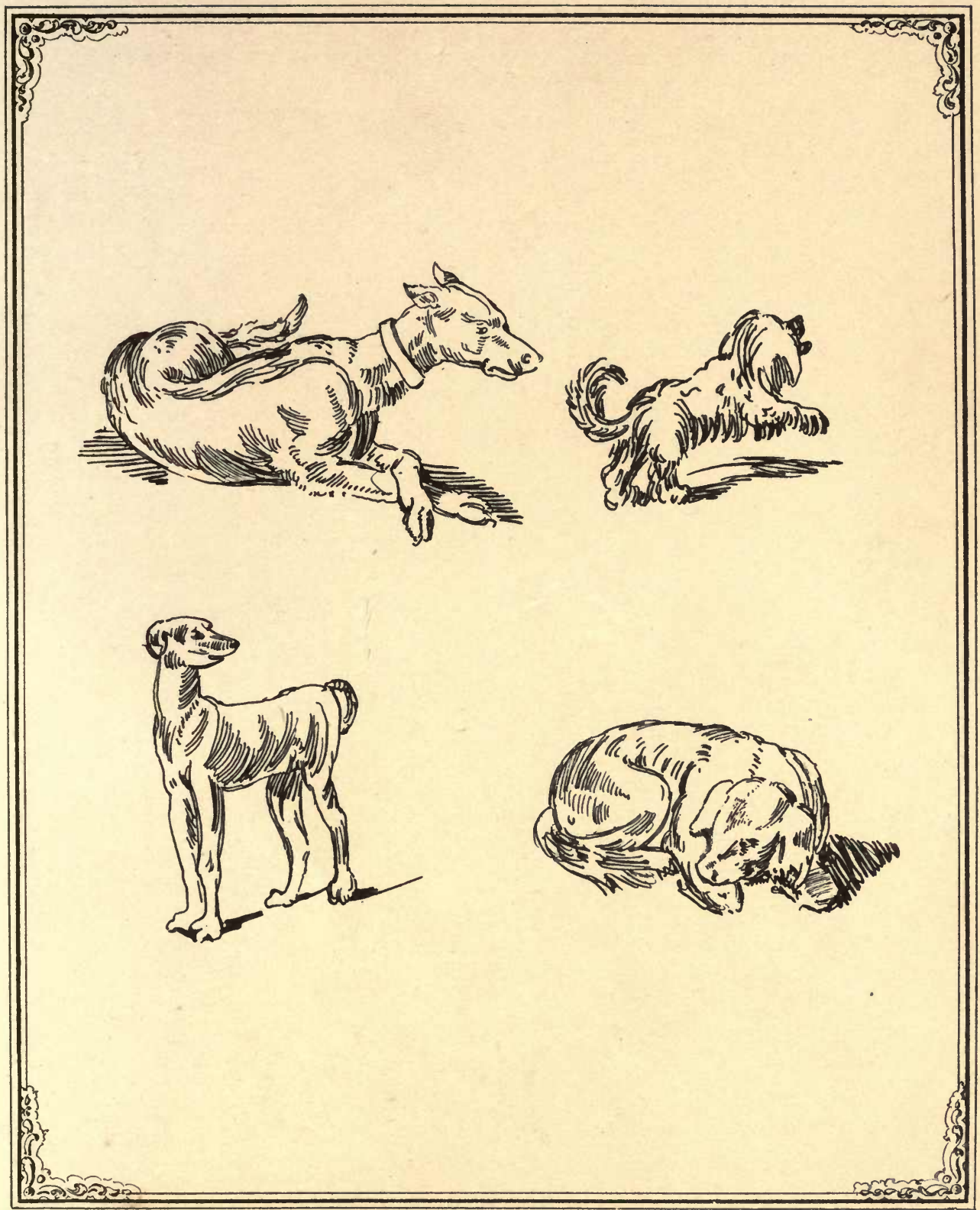

MARTIN DE VOS, $\quad 1579-1586$. 



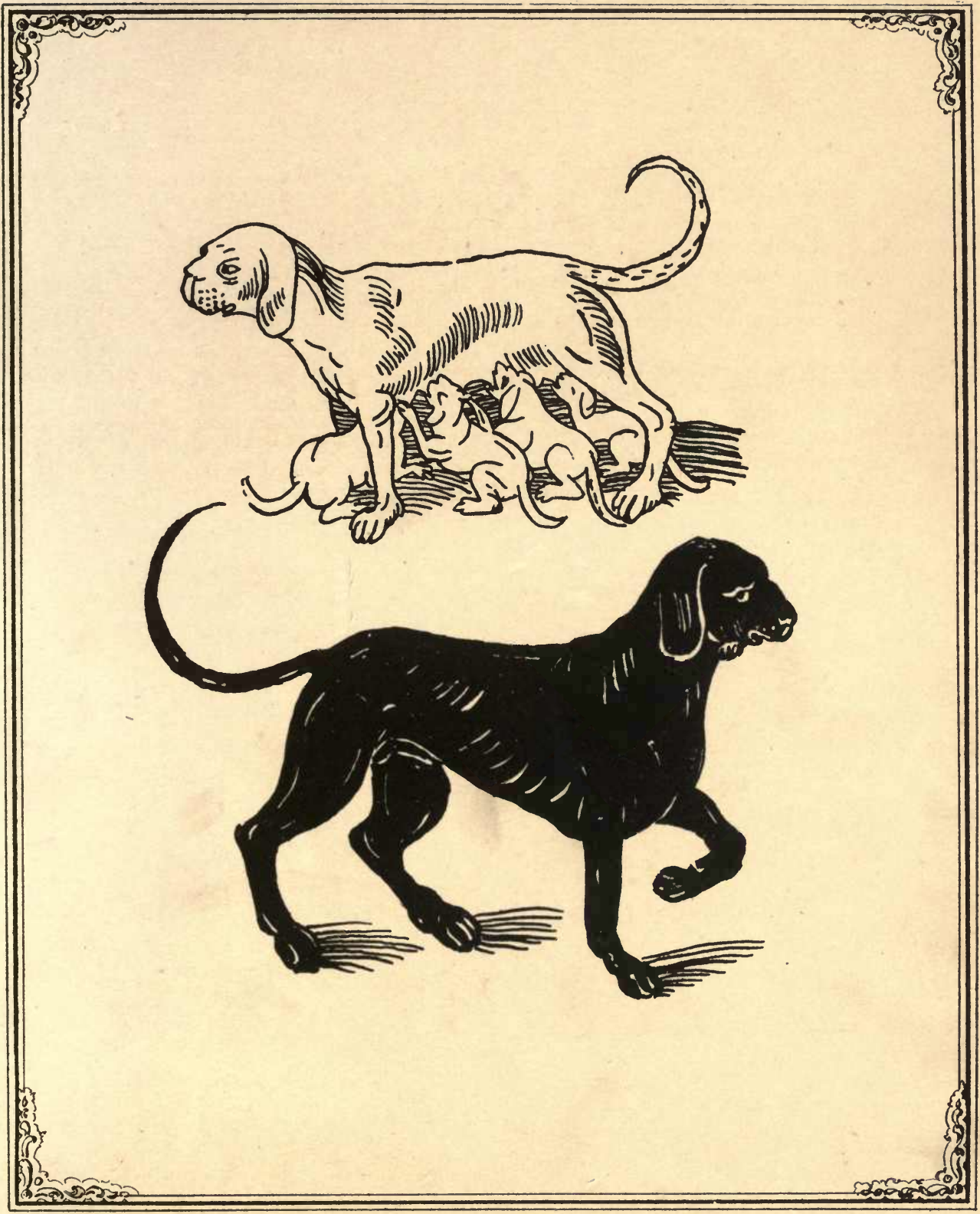





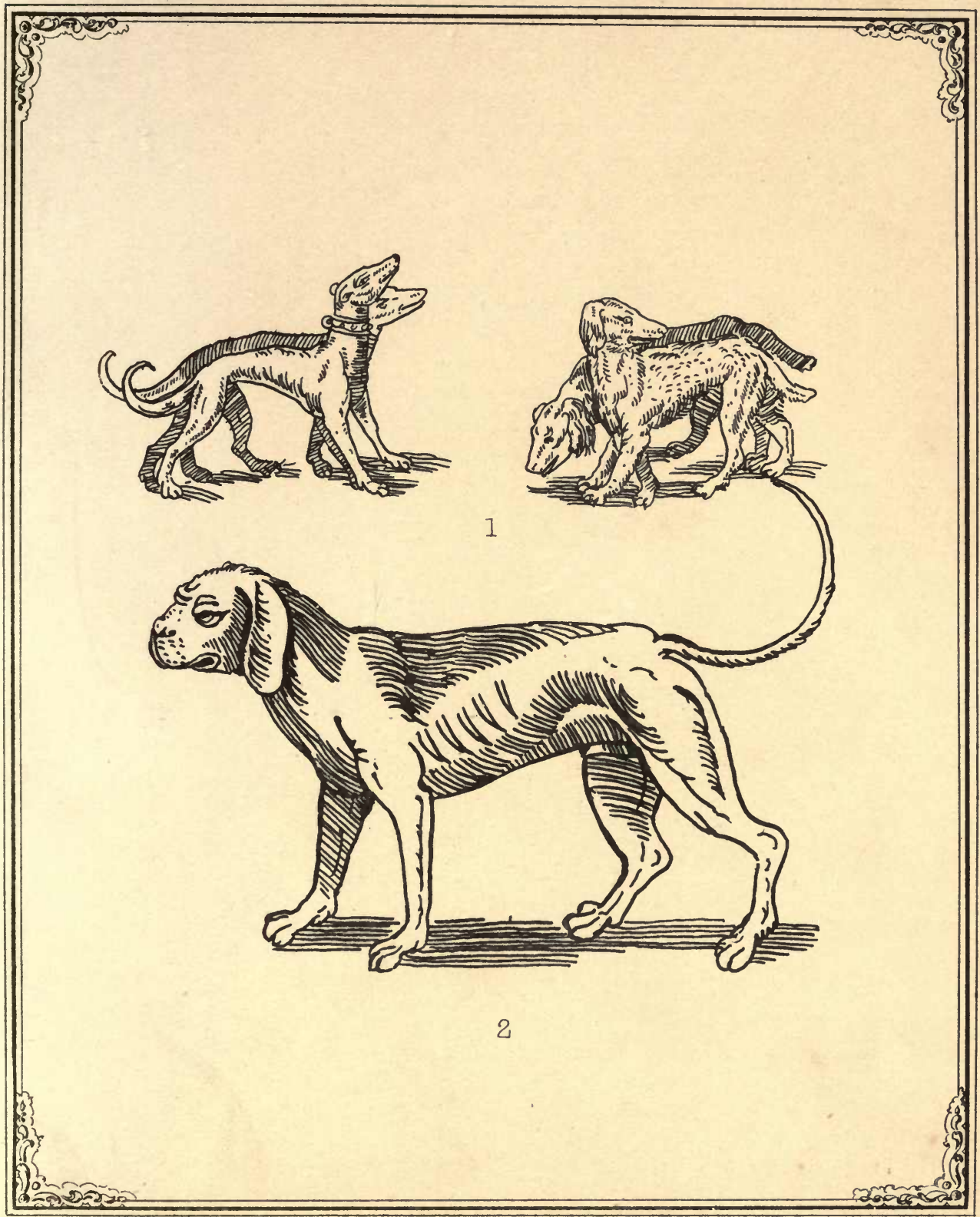





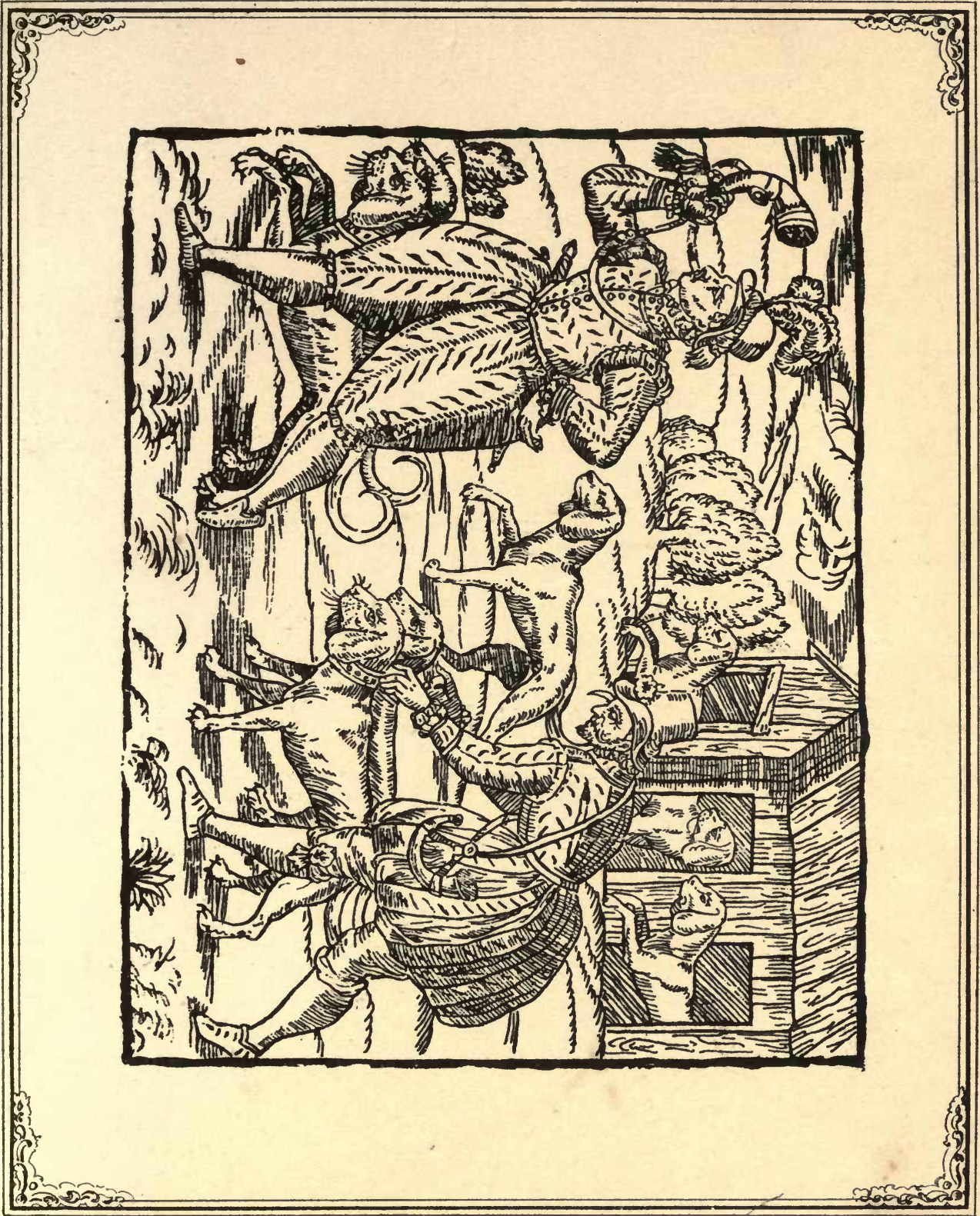





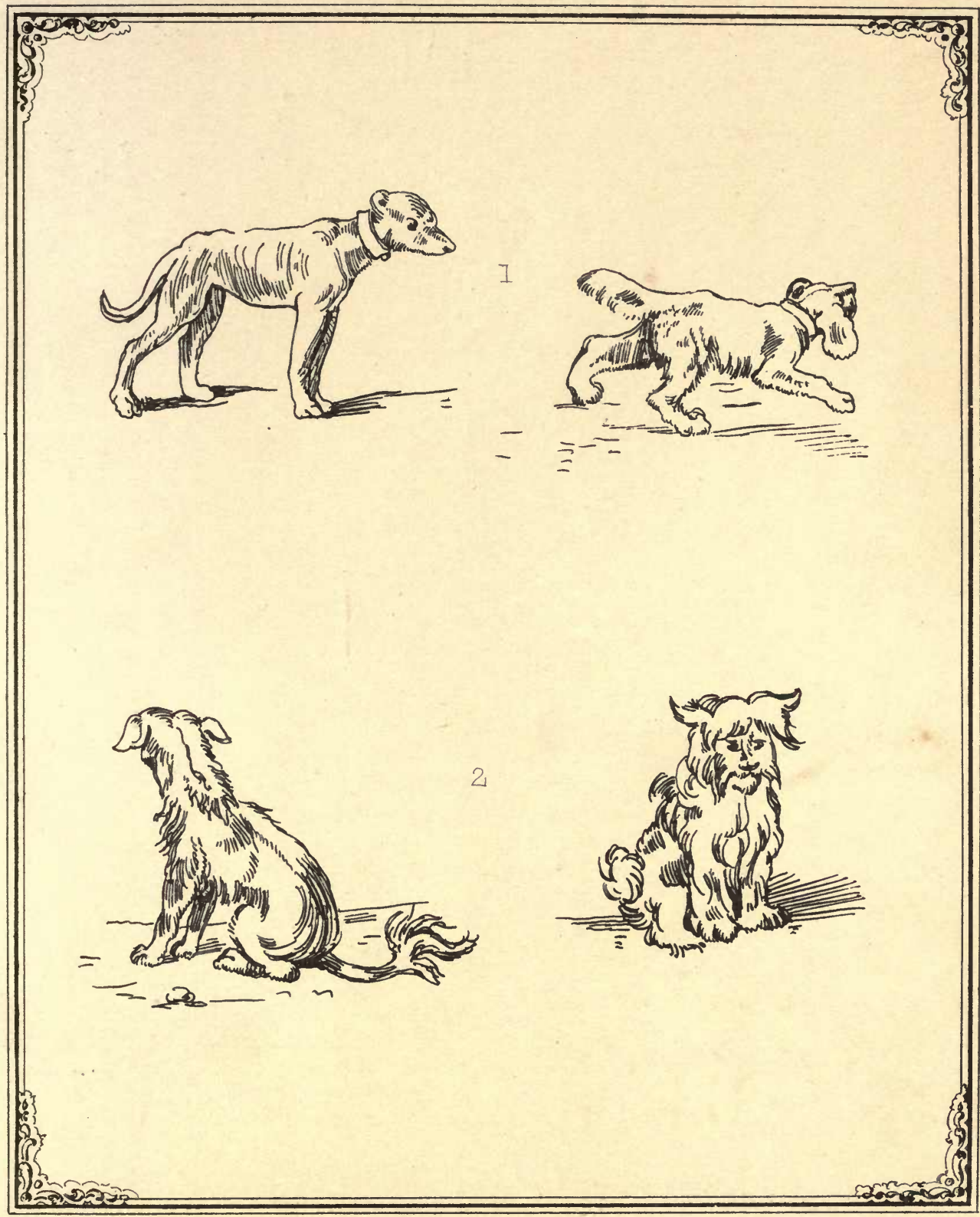

(1) LONDERSEEL, 1586 . (2) MIAIR, 1501. 



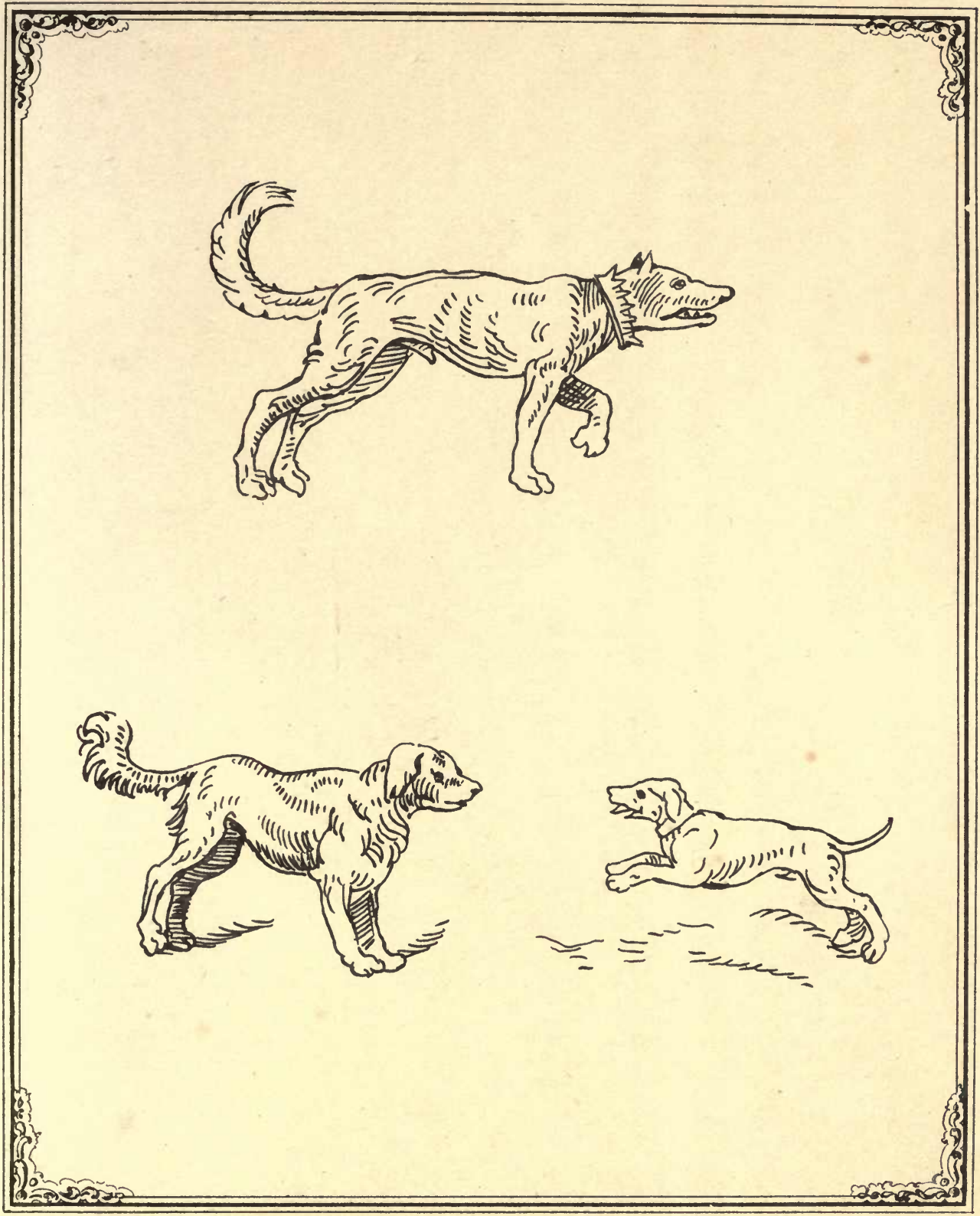

HANS SCHAEUFLEIN, 1520. 



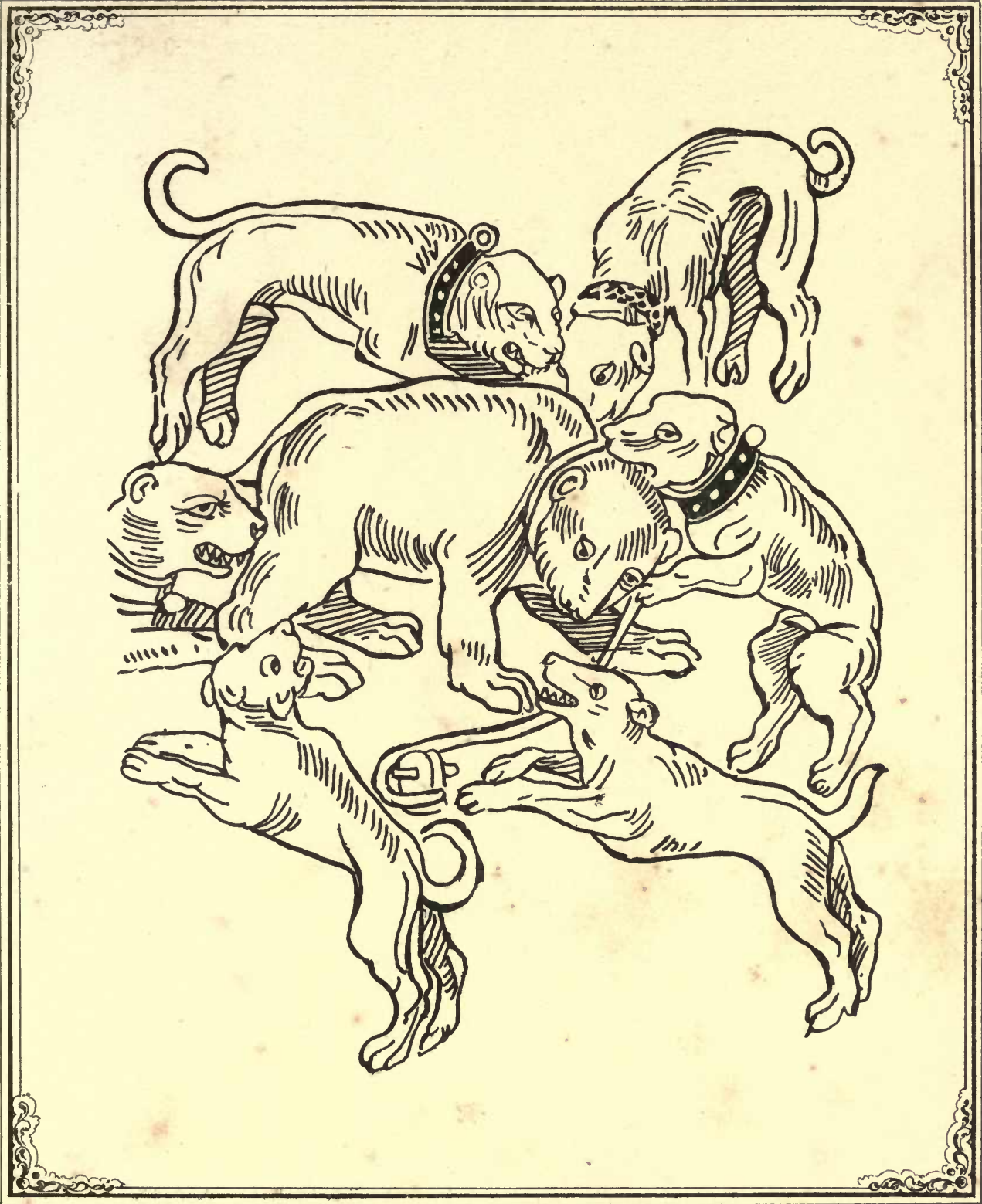




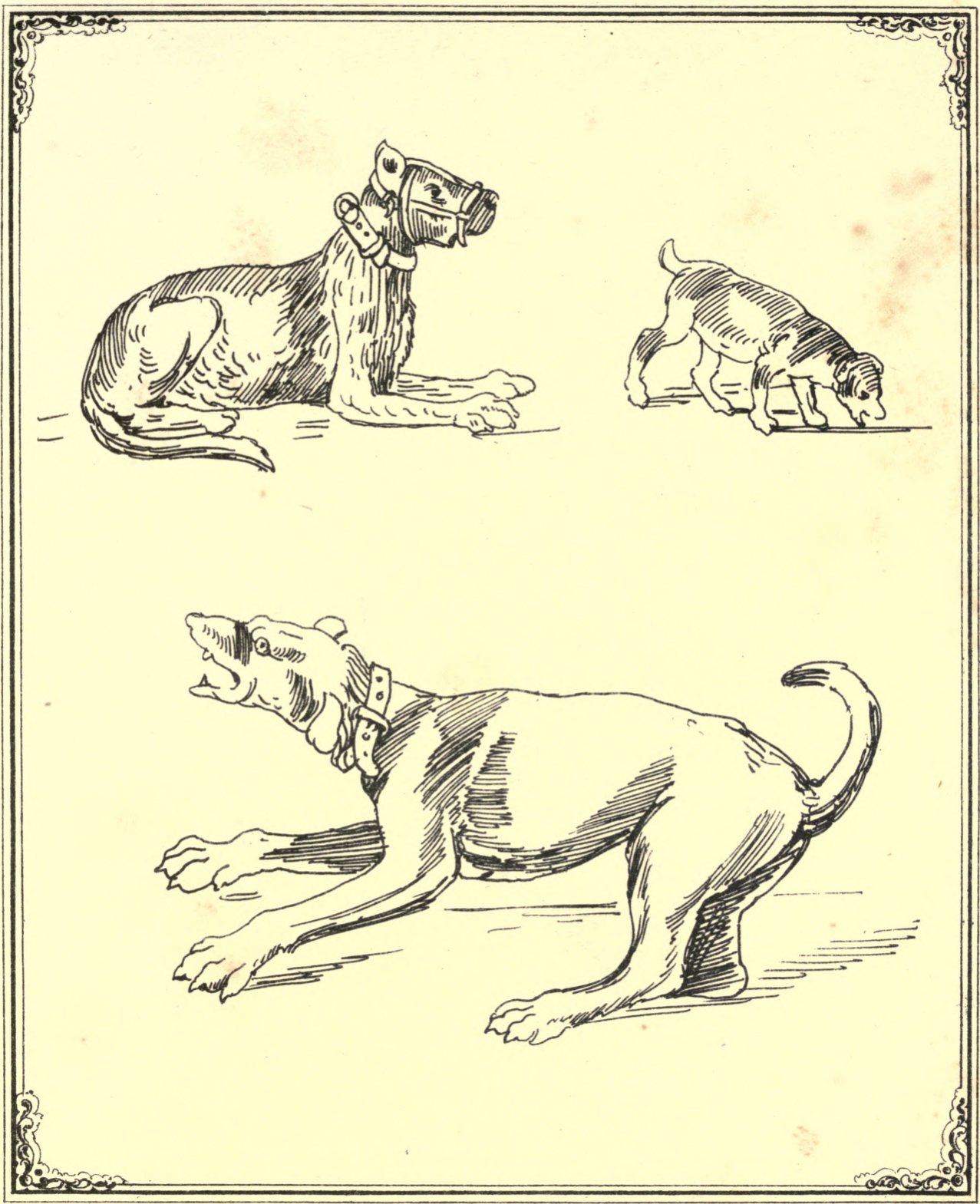


ton

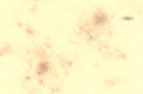




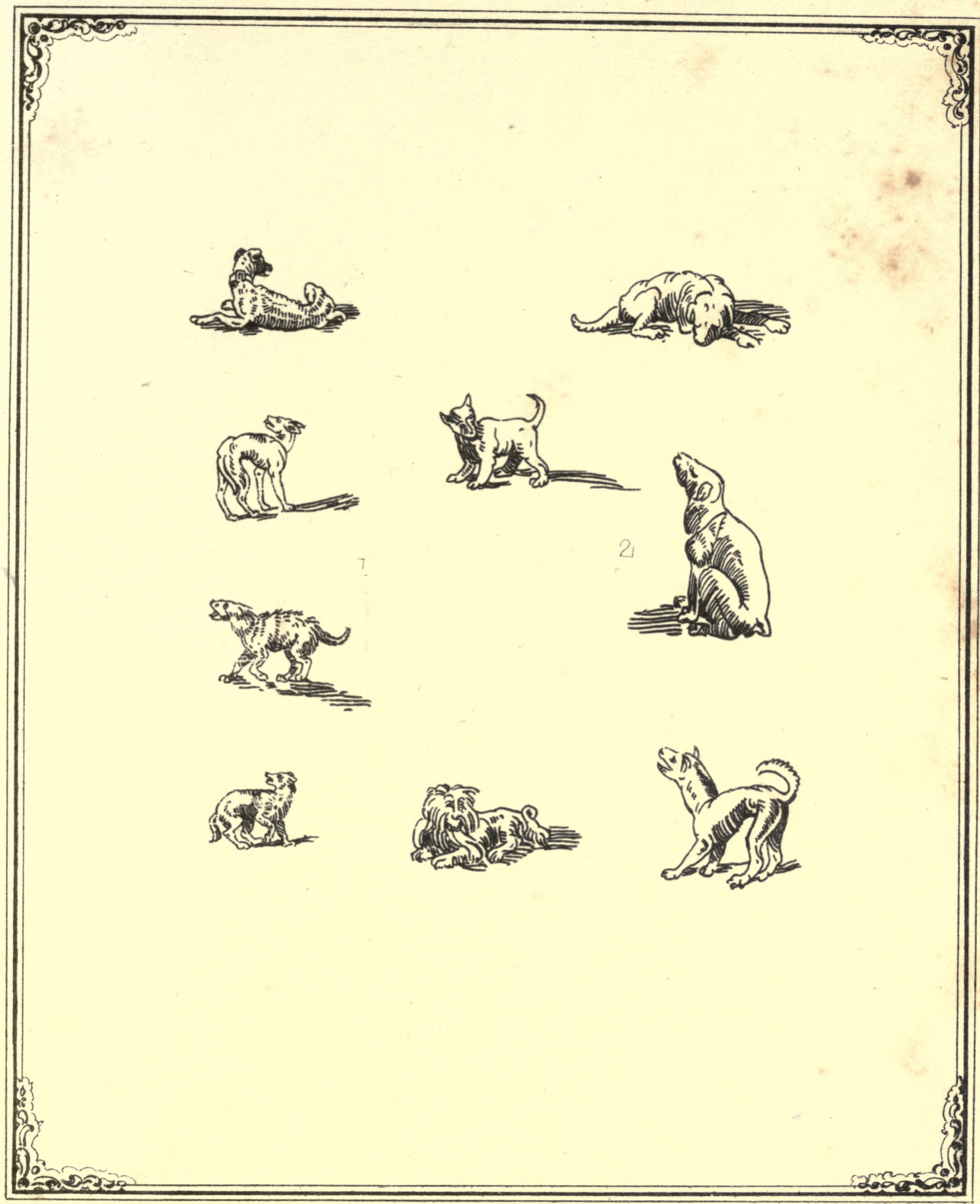





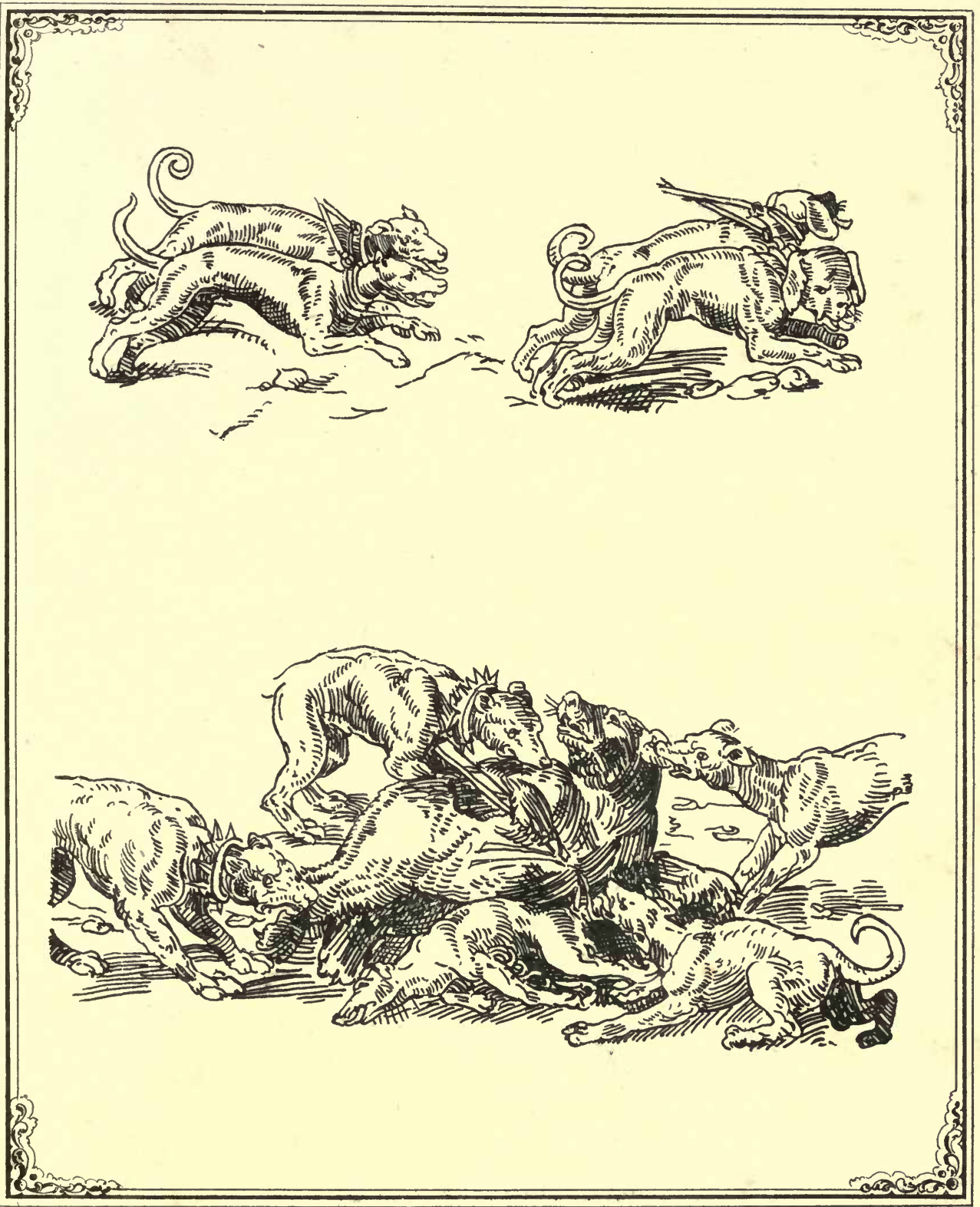




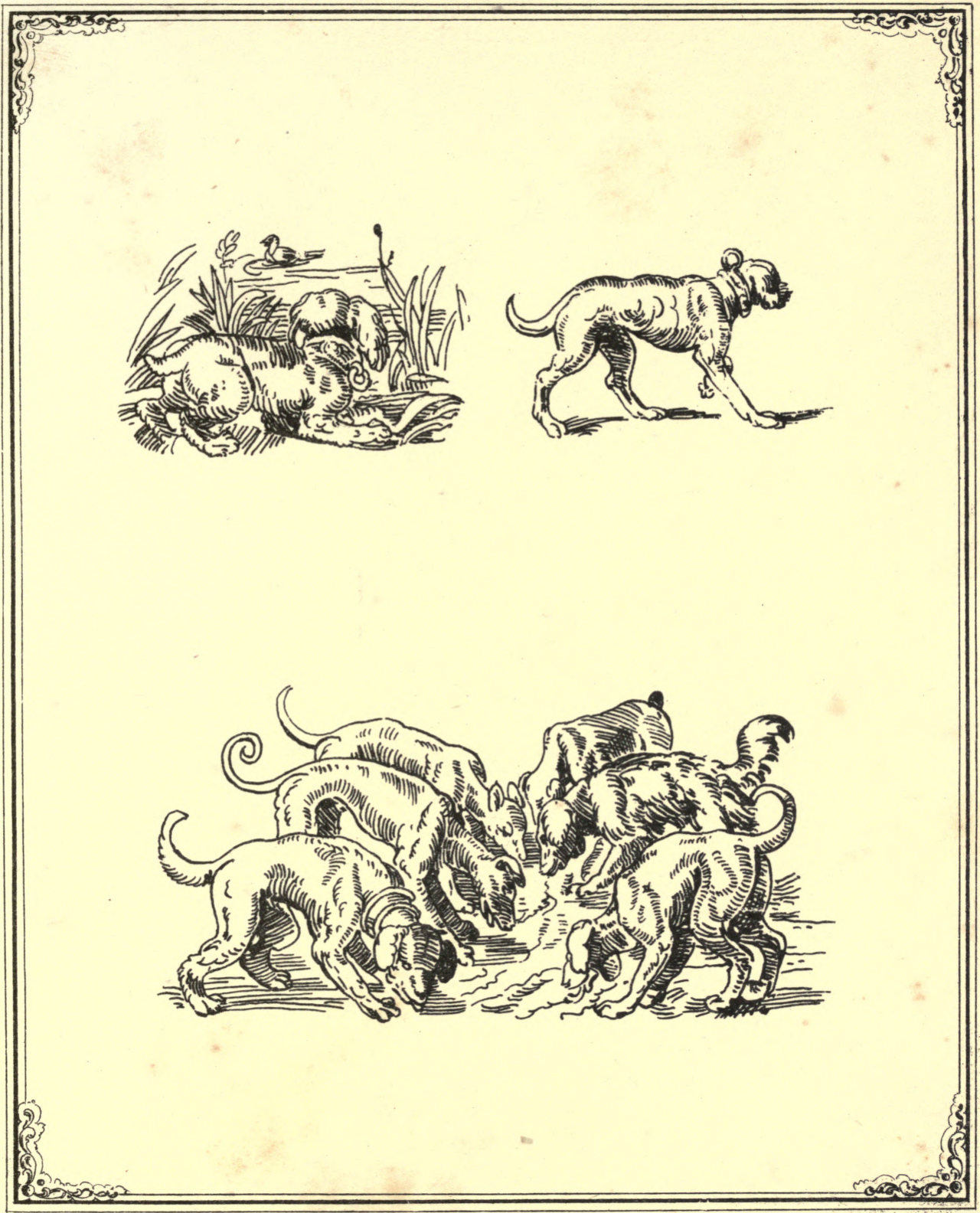





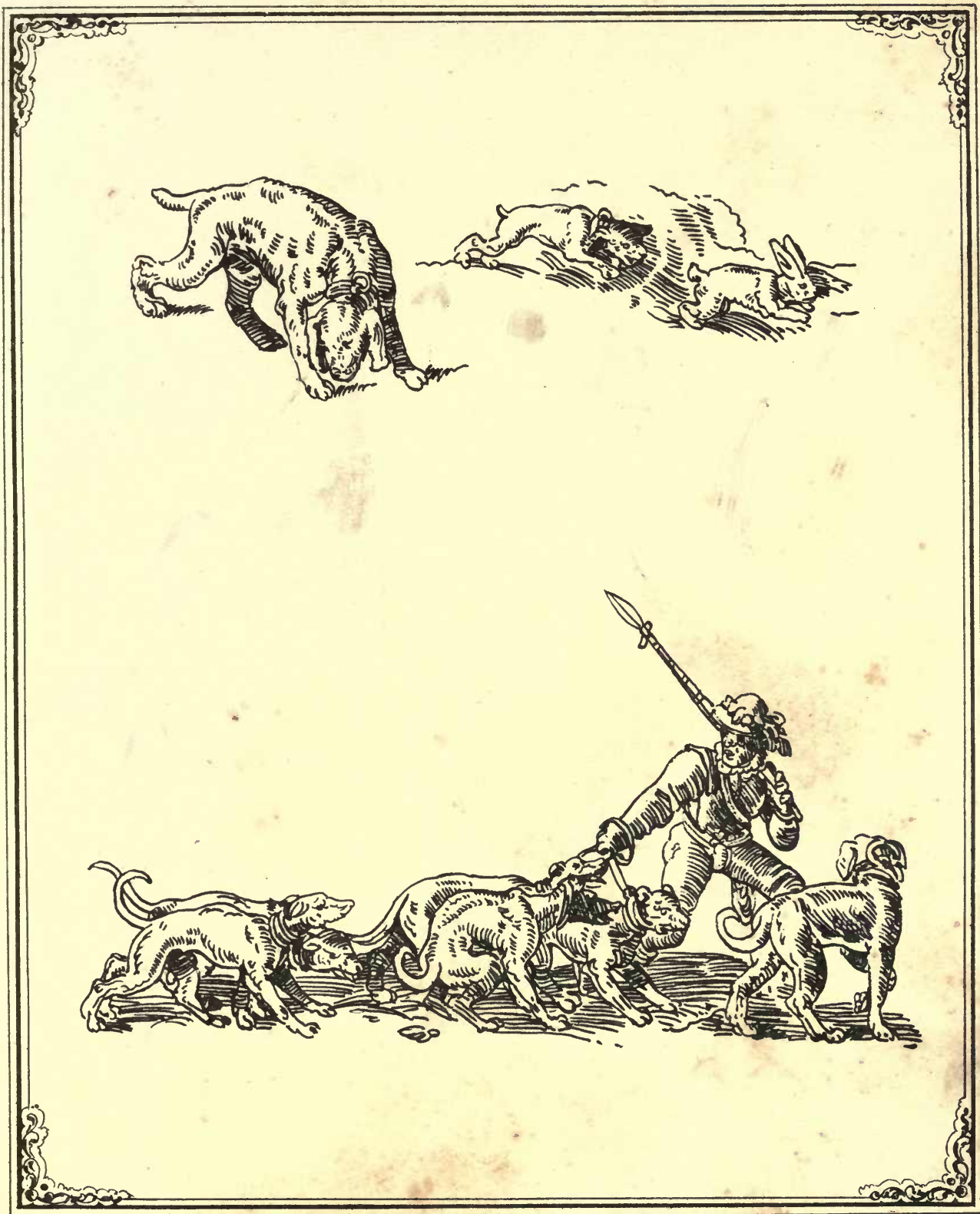





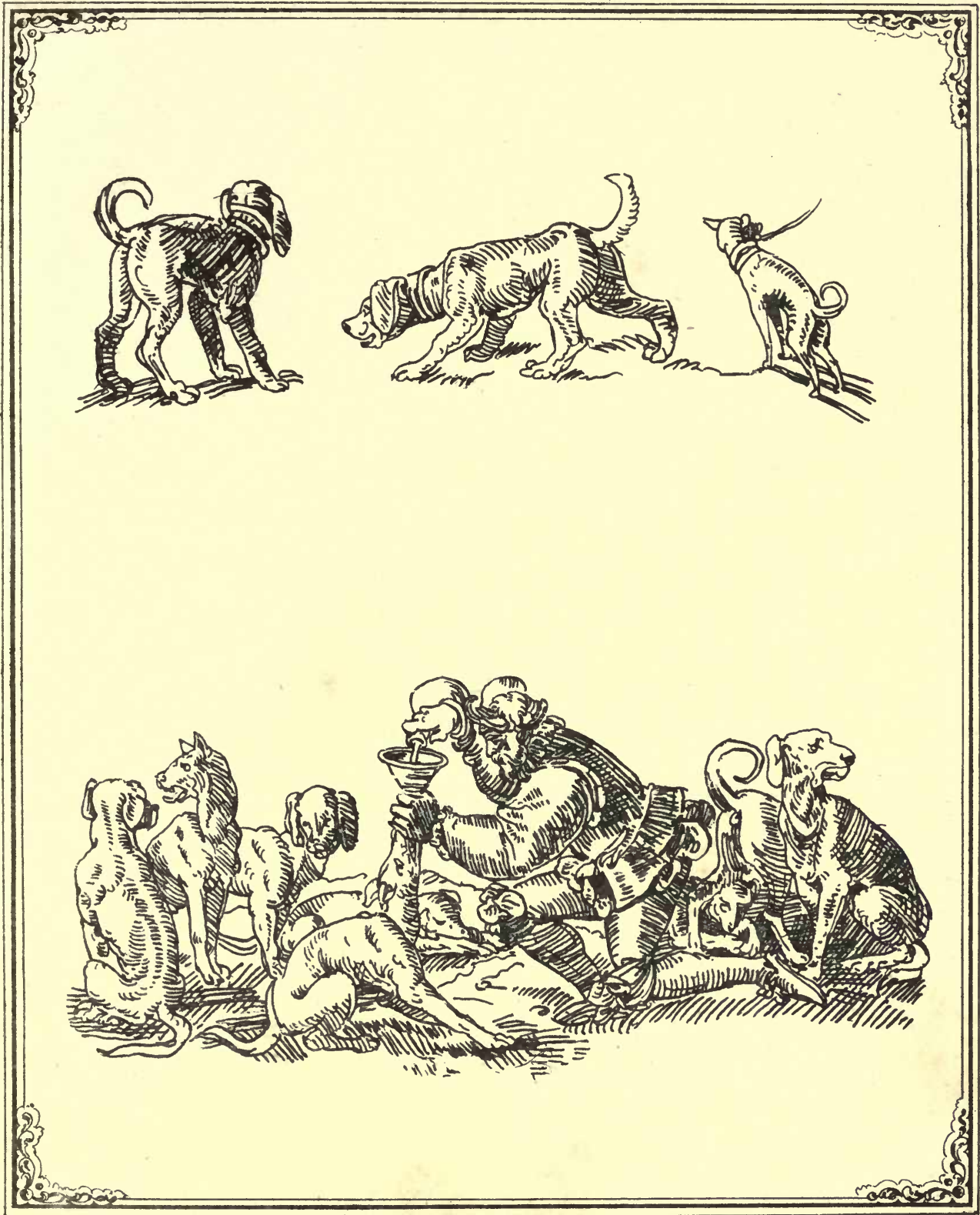





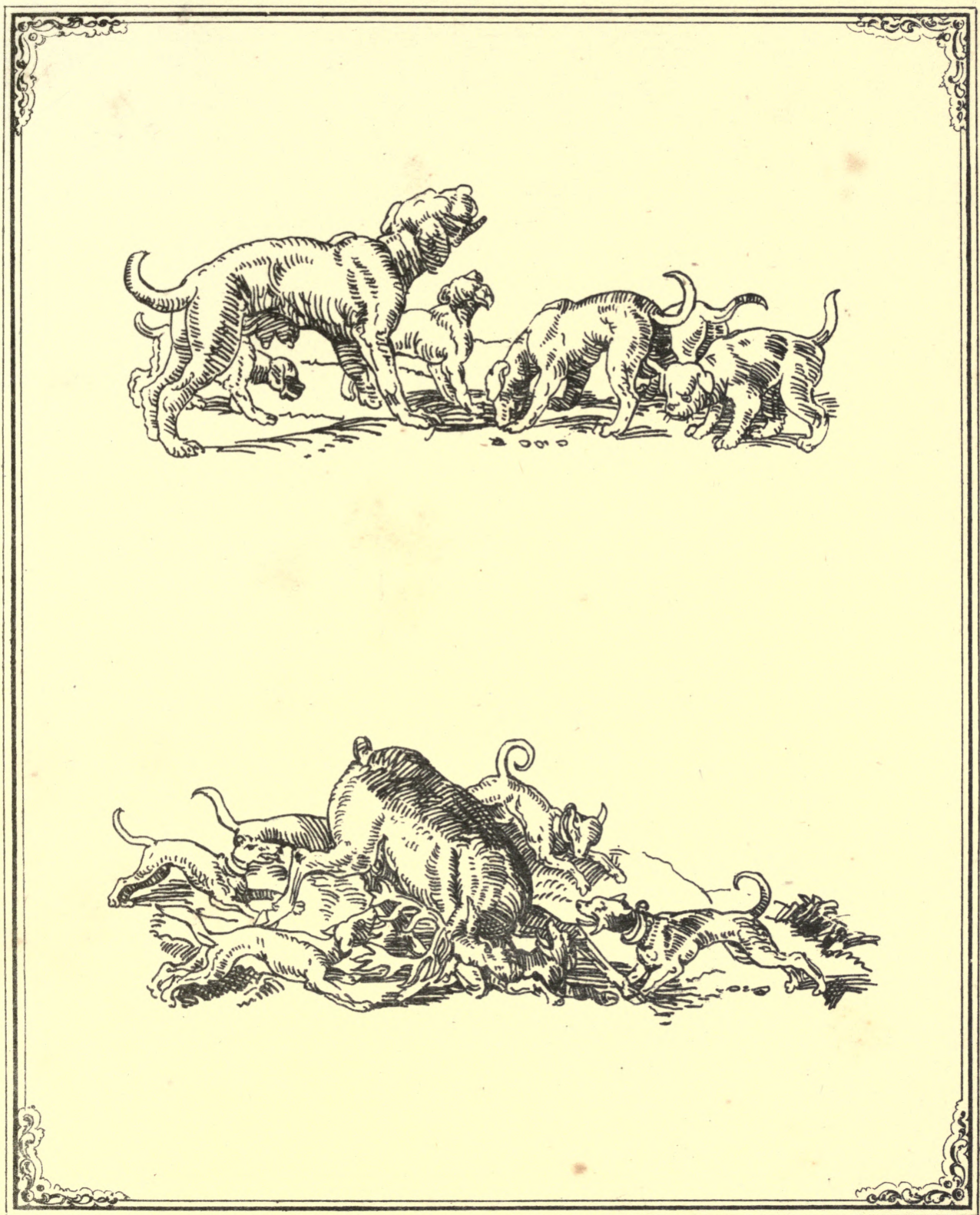


xes 


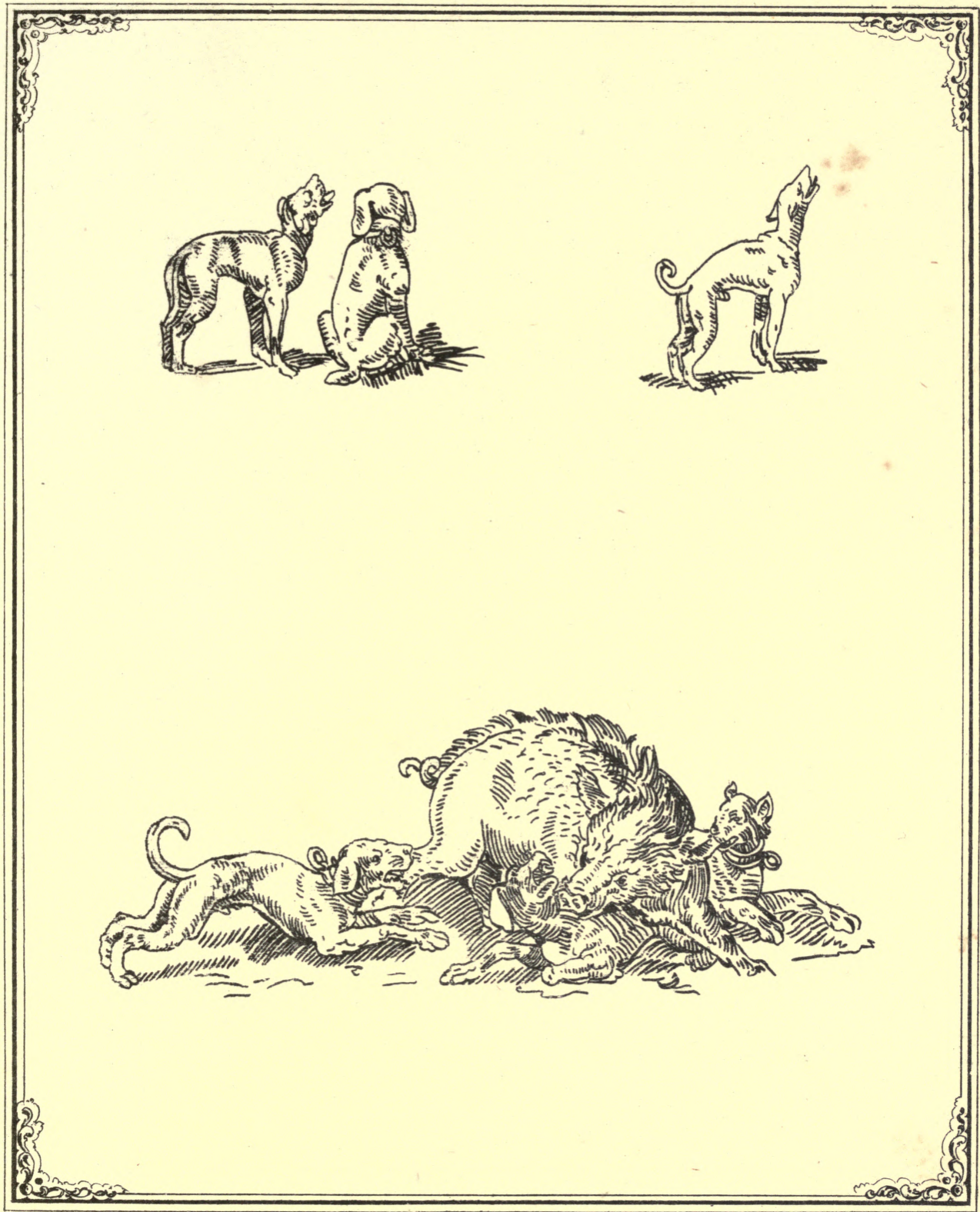


난.

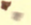


42

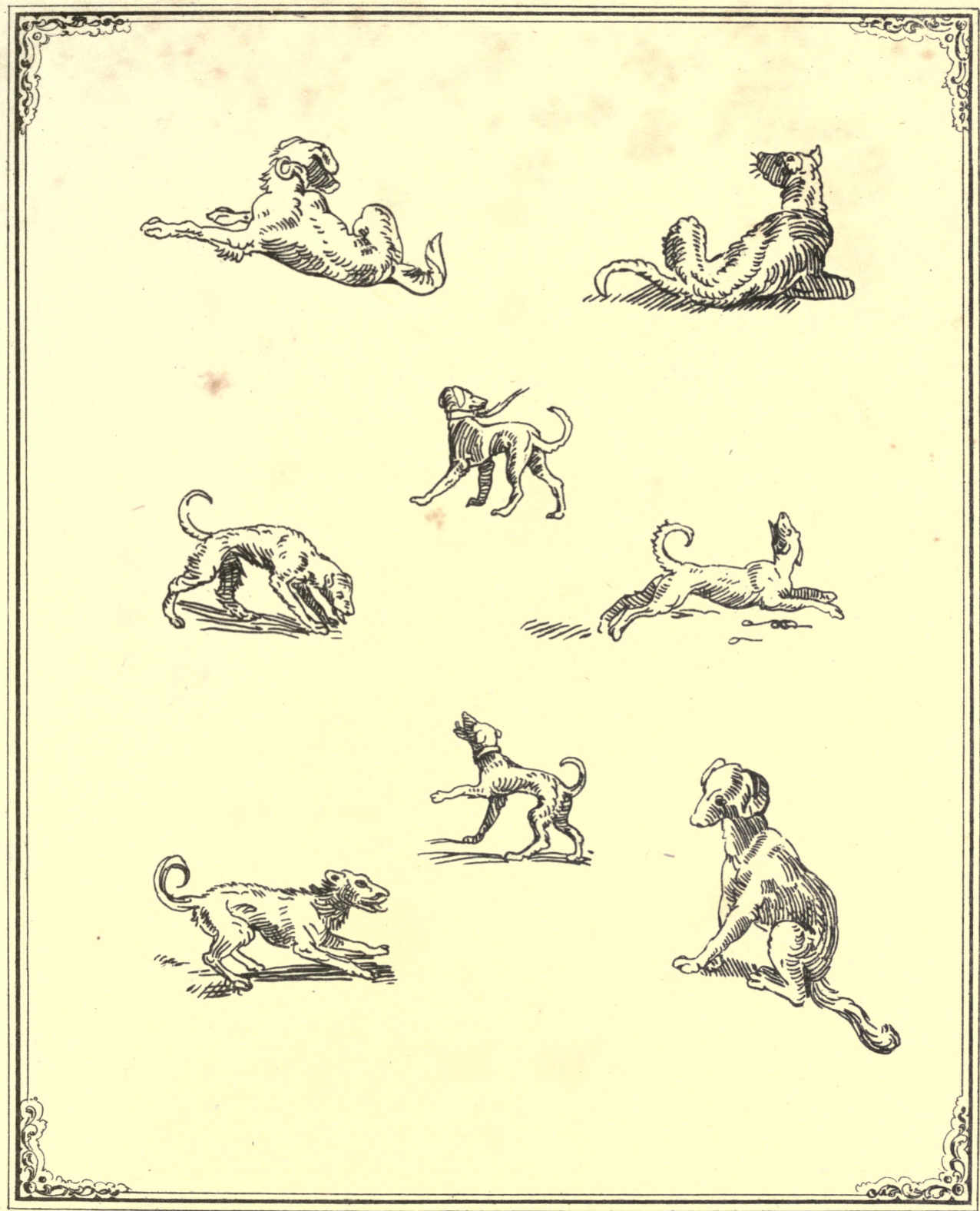



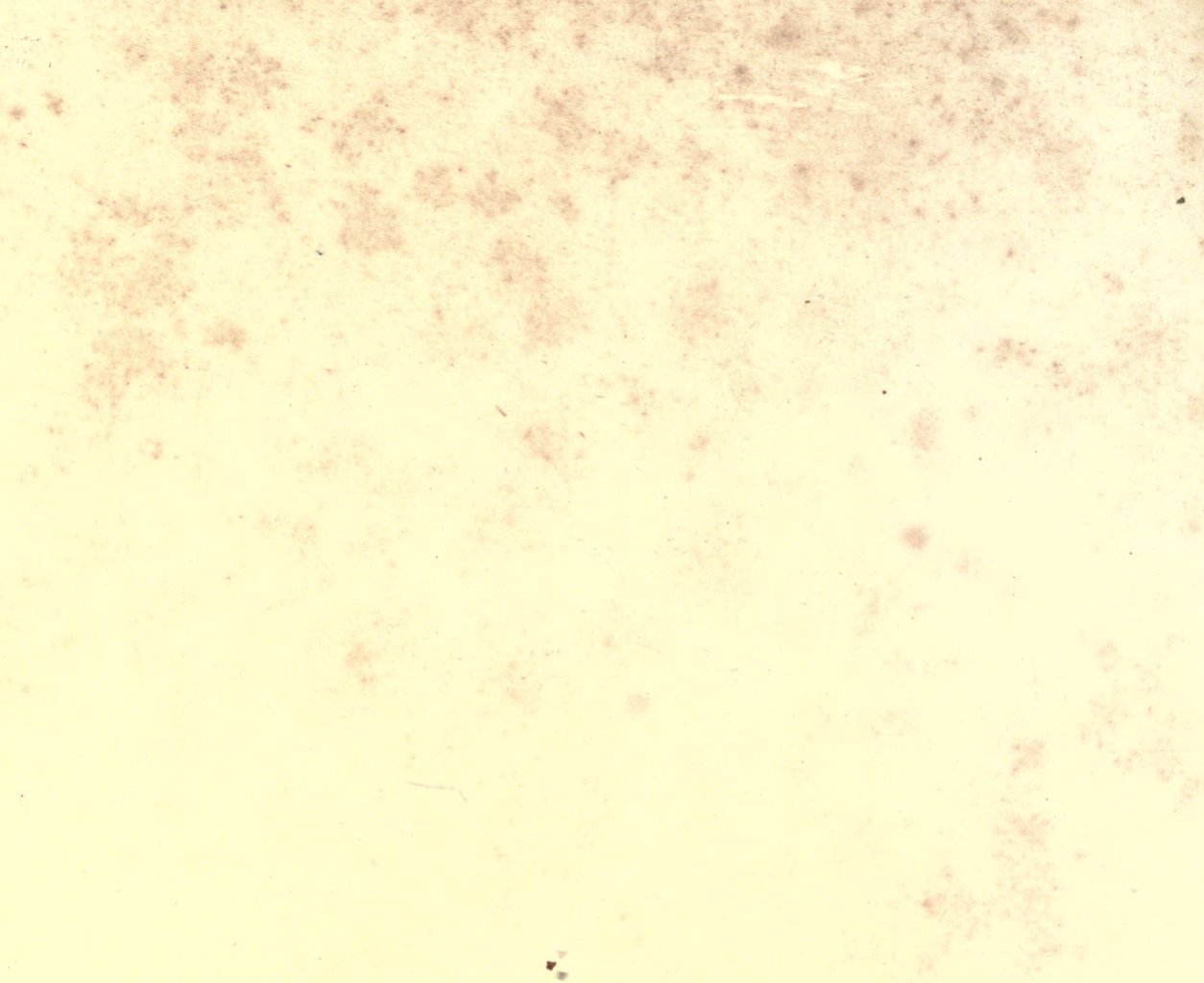


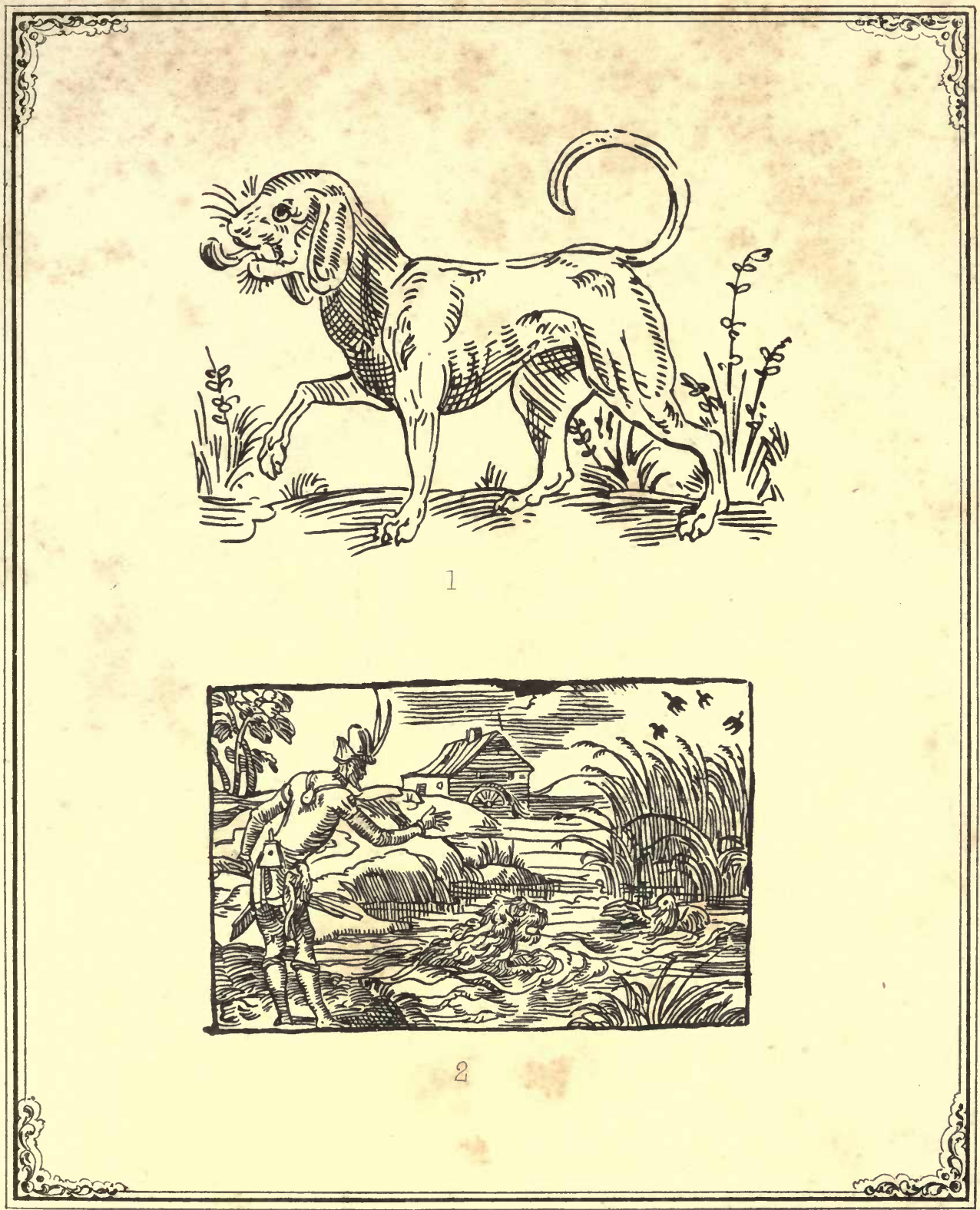

(1) TH: COKAINE, 159!. (21) IAN DE TOVRNES, 1556. 



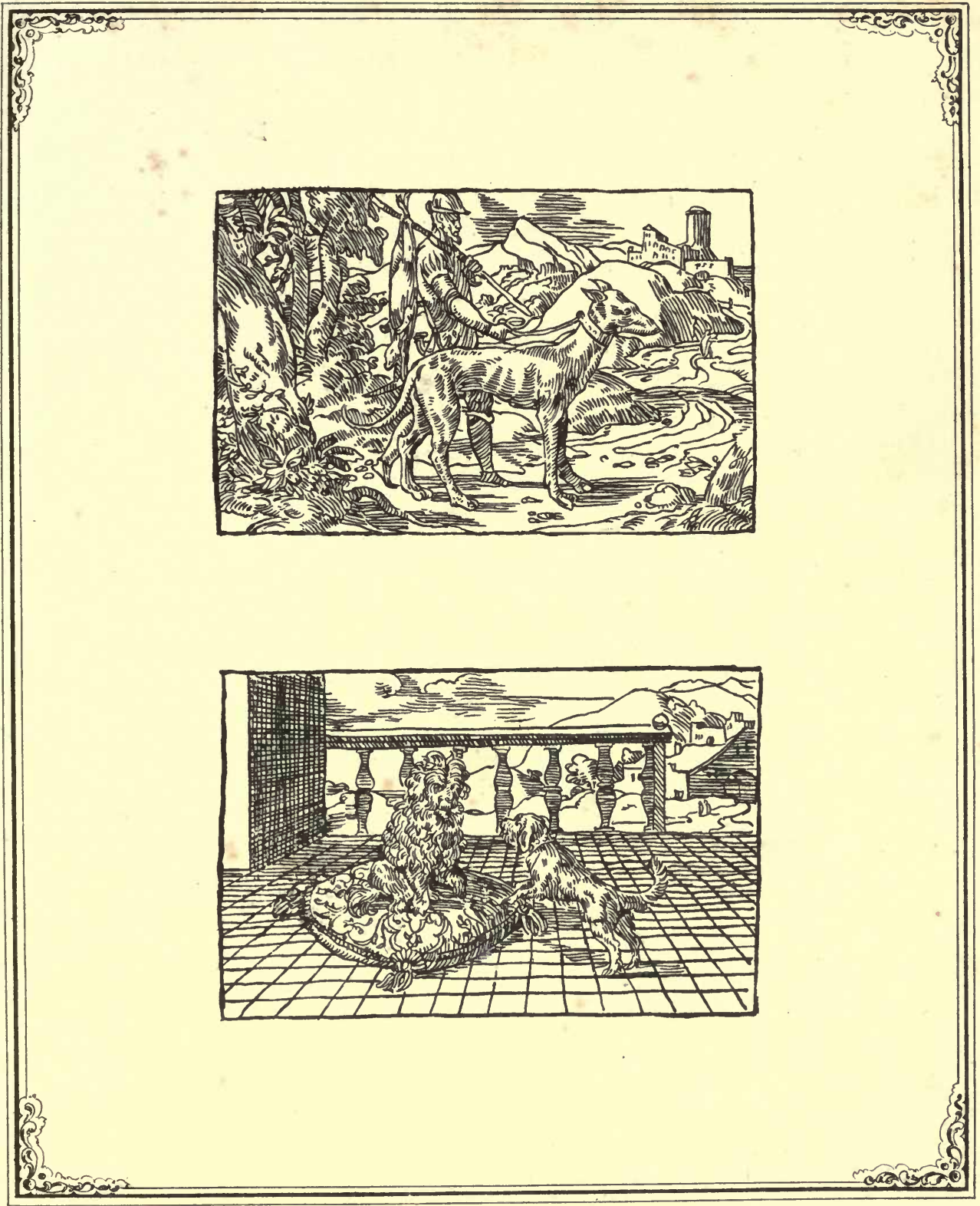




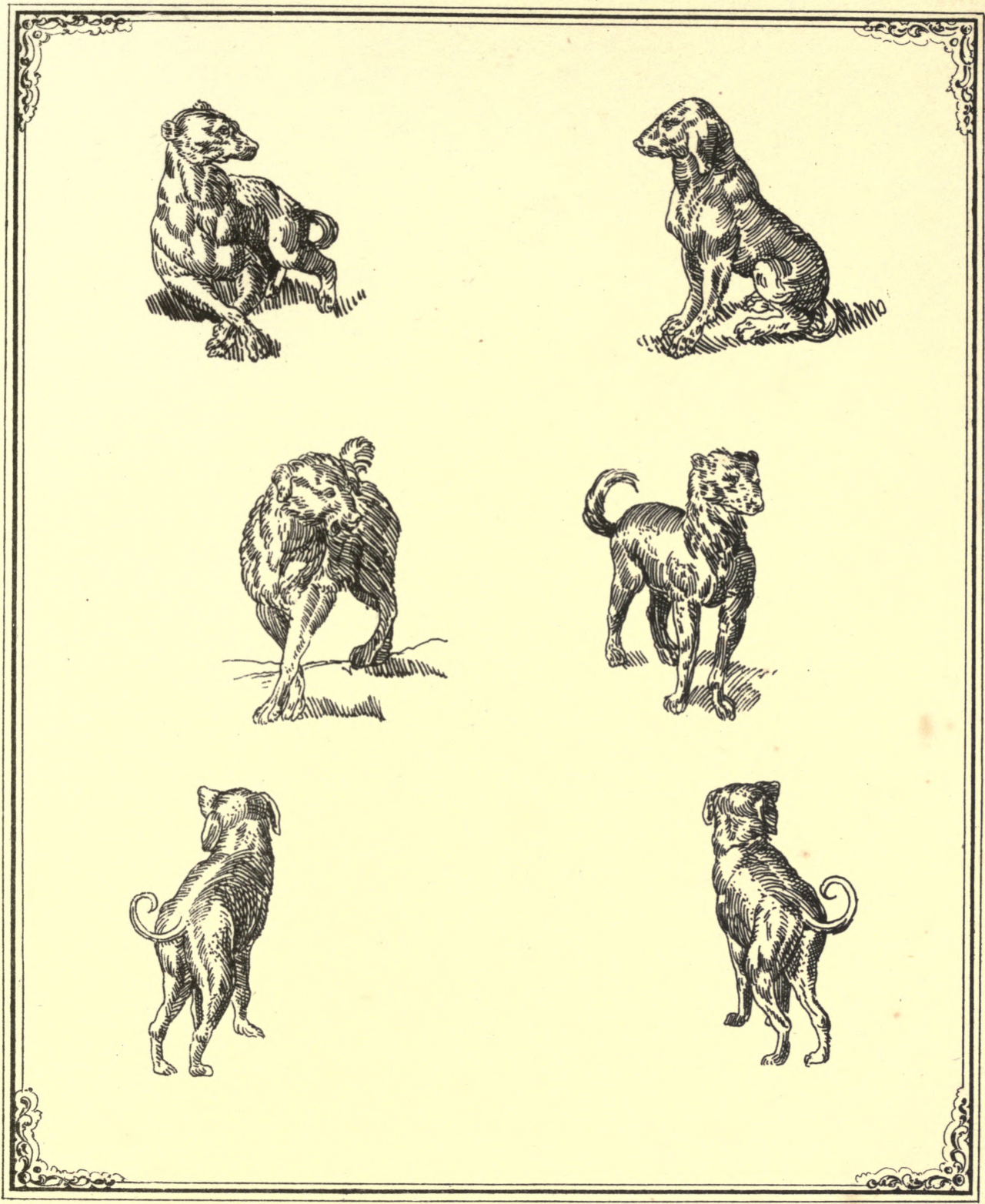

\section{TH. DE BRY, 1647.}




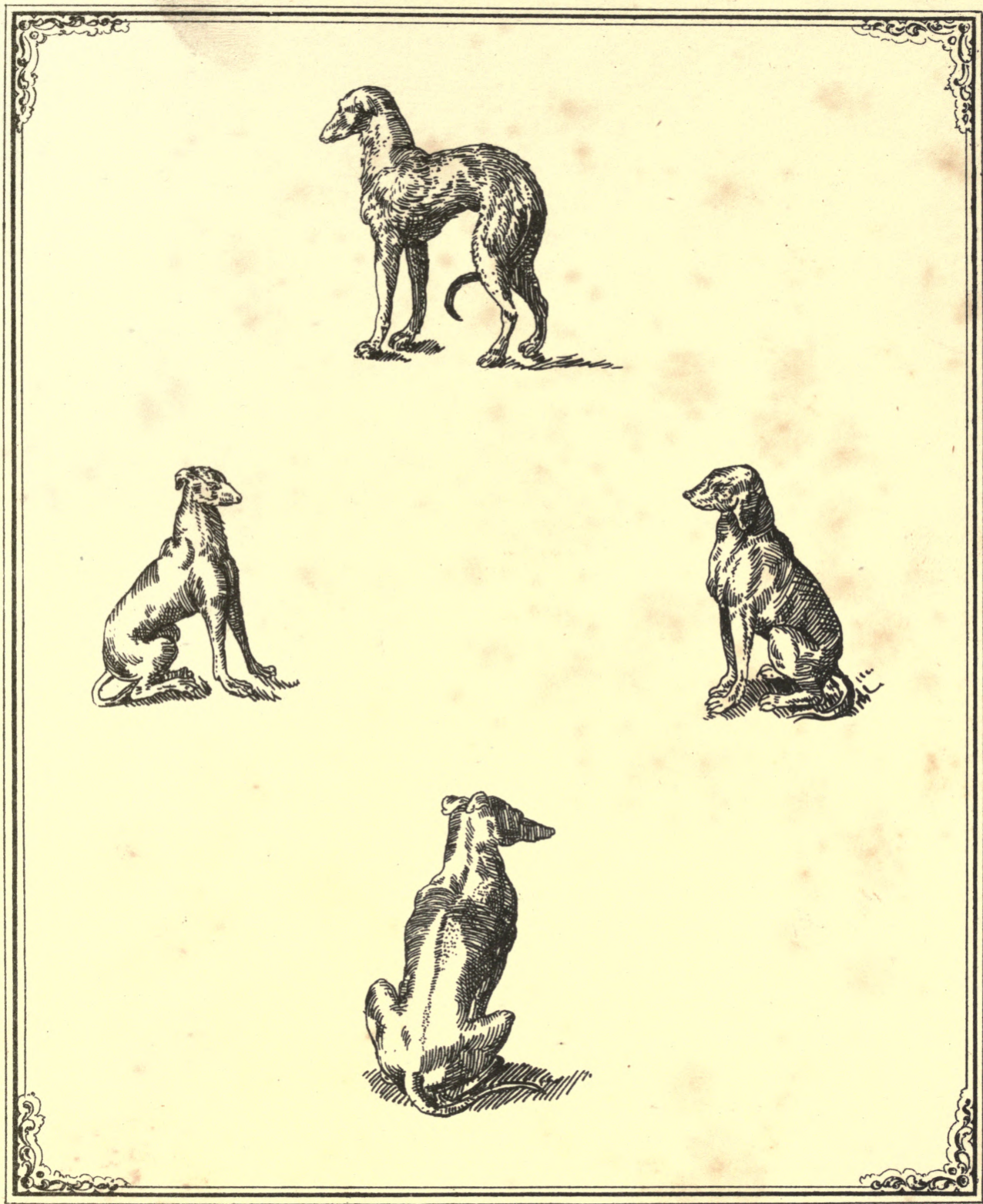

TH DE BRY, 1647. 
1 


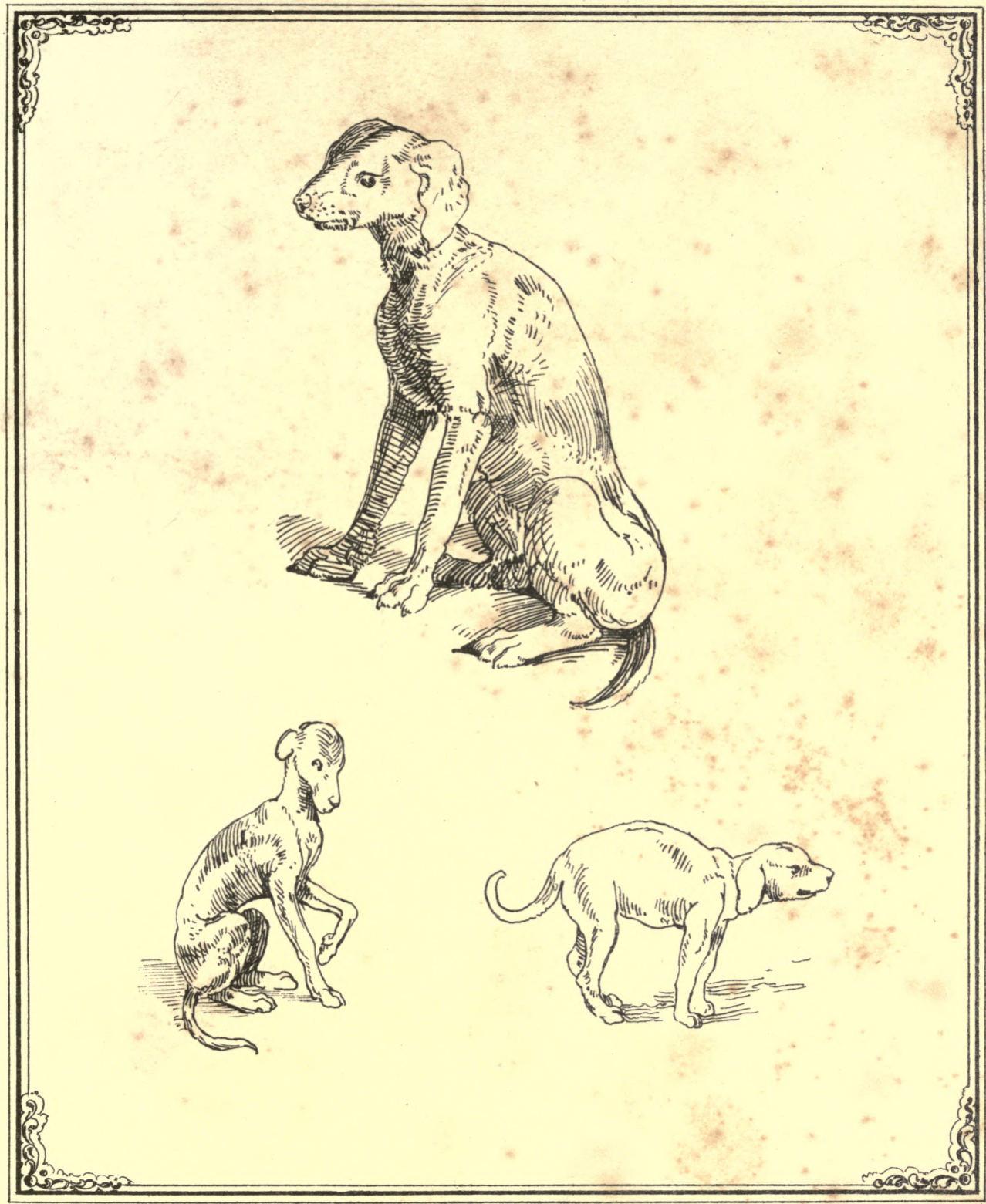

BECKERVELD, 1626. 



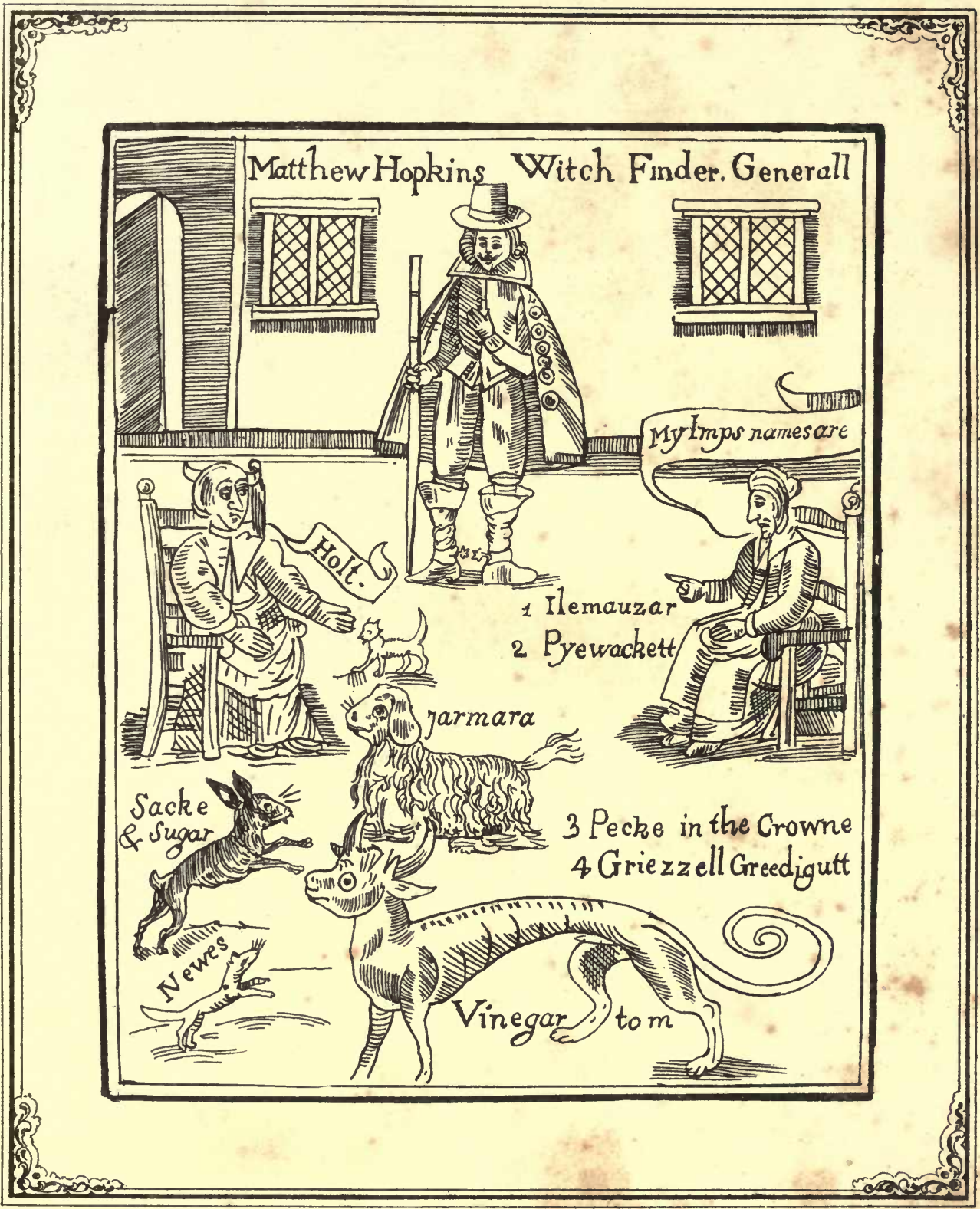





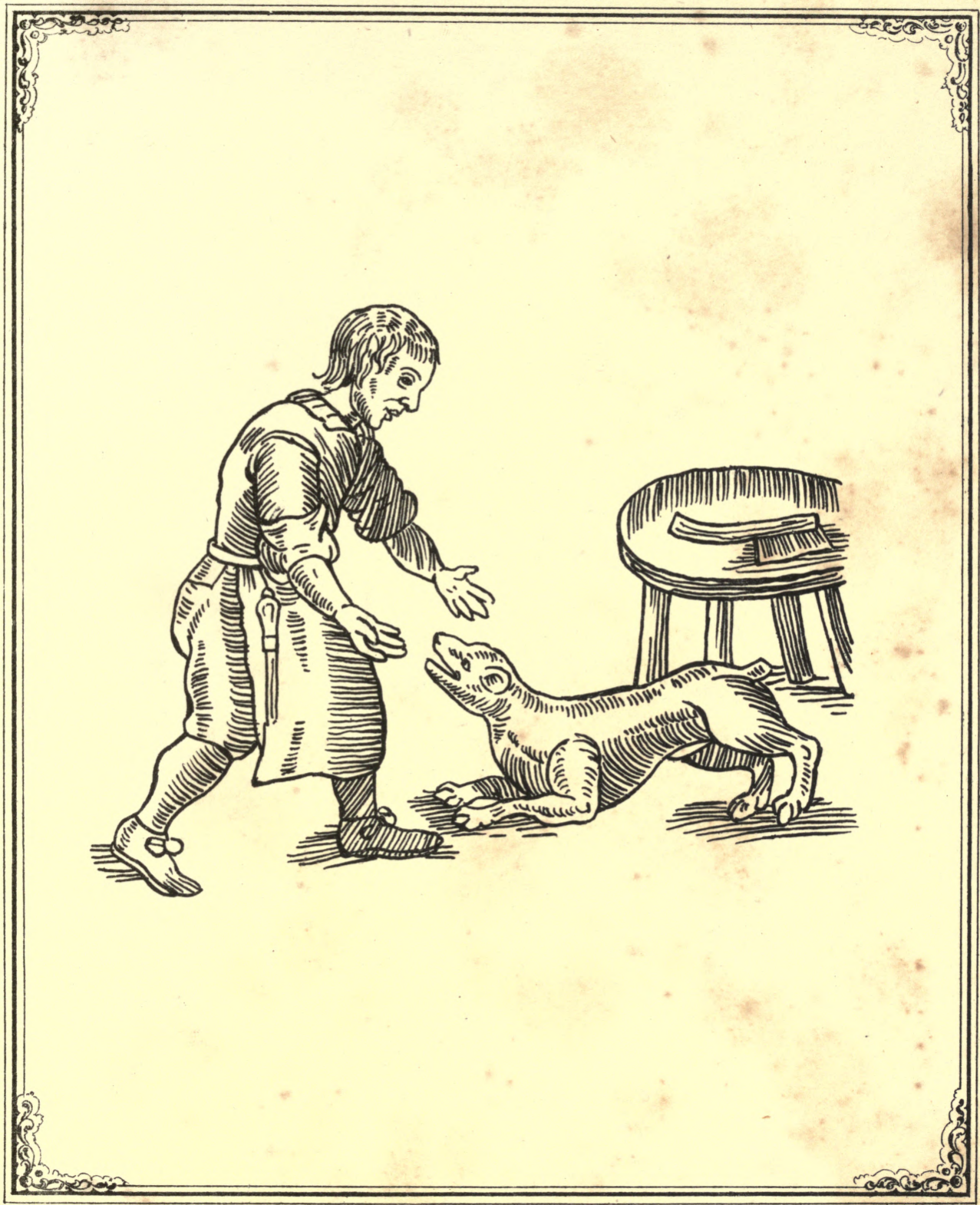

FRON HIND, THE GREAT ROBBER, WHEN HE WAS A BUTCHER'S BOY. 1652. 


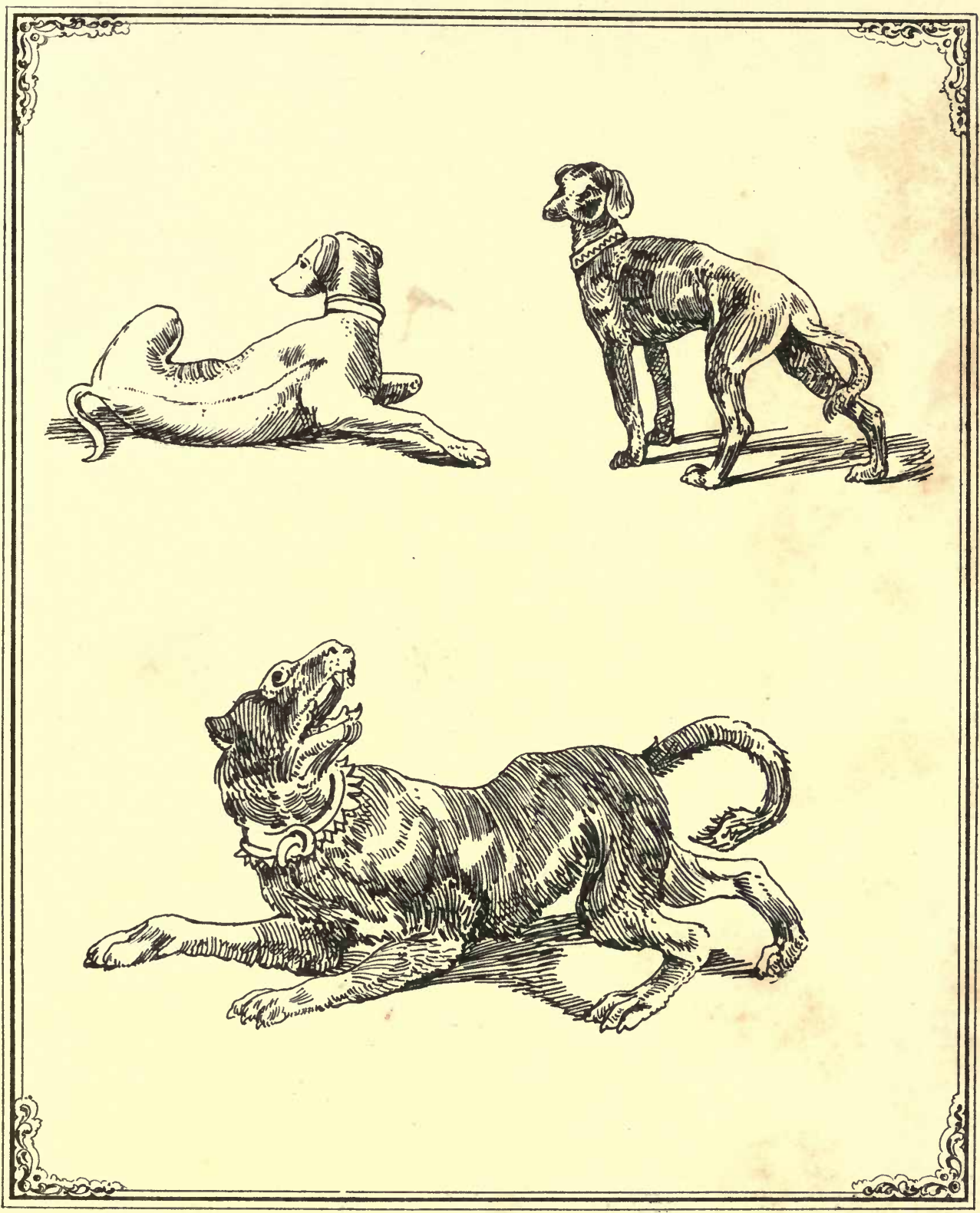




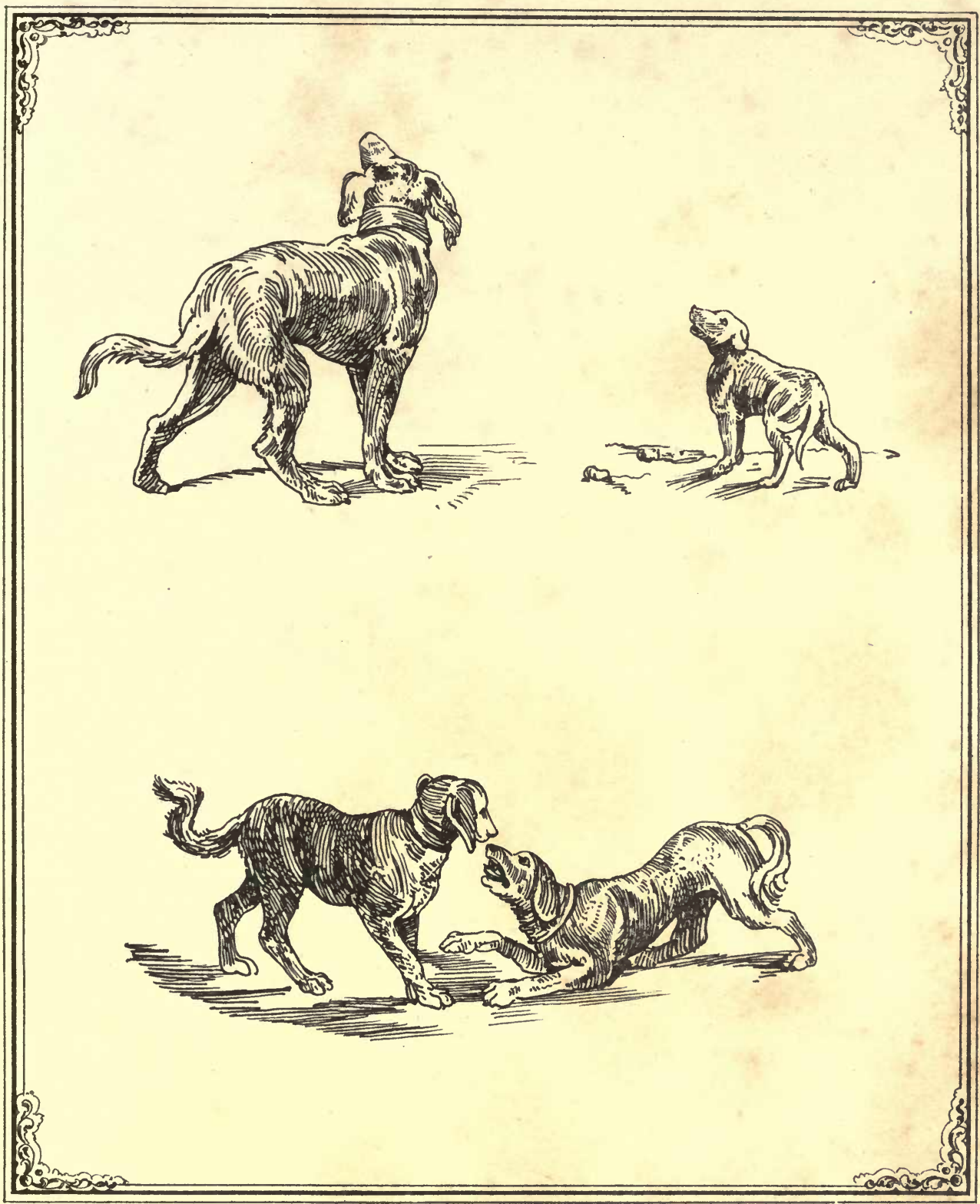

WILLIAMI FAITHORNE, 1660. 



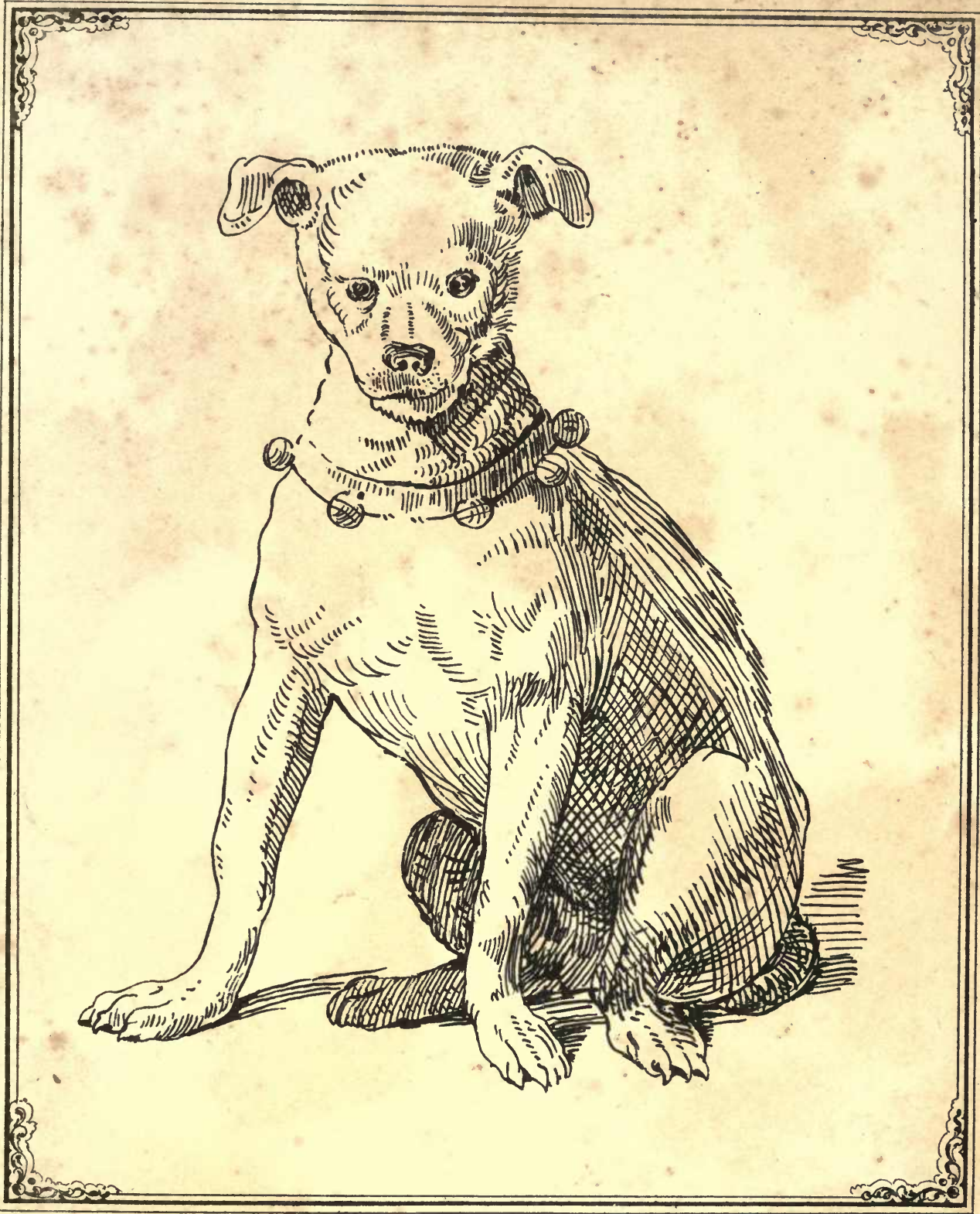






RETURN TO the circulation desk of any University of California Library or to the

LO NORTHERN REGIONAL LIBRARY FACILITY Bldg. 400, Richmond Field Station University of California Richmond, CA 94804-4698

ALL BOOKS MAY BE RECALLED AFTER 7 DAYS

- 2-month loans may be renewed by calling (510) 642-6753

- 1-year loans may be recharged by bringing books to NRLF

- Renewals and recharges may be made 4 days prior to due date.

DUE AS STAMPED BELOW

\section{OCT 022002}

FC 


\section{yn 04484}

\section{U.C. BERKELEY LIBRARIES}
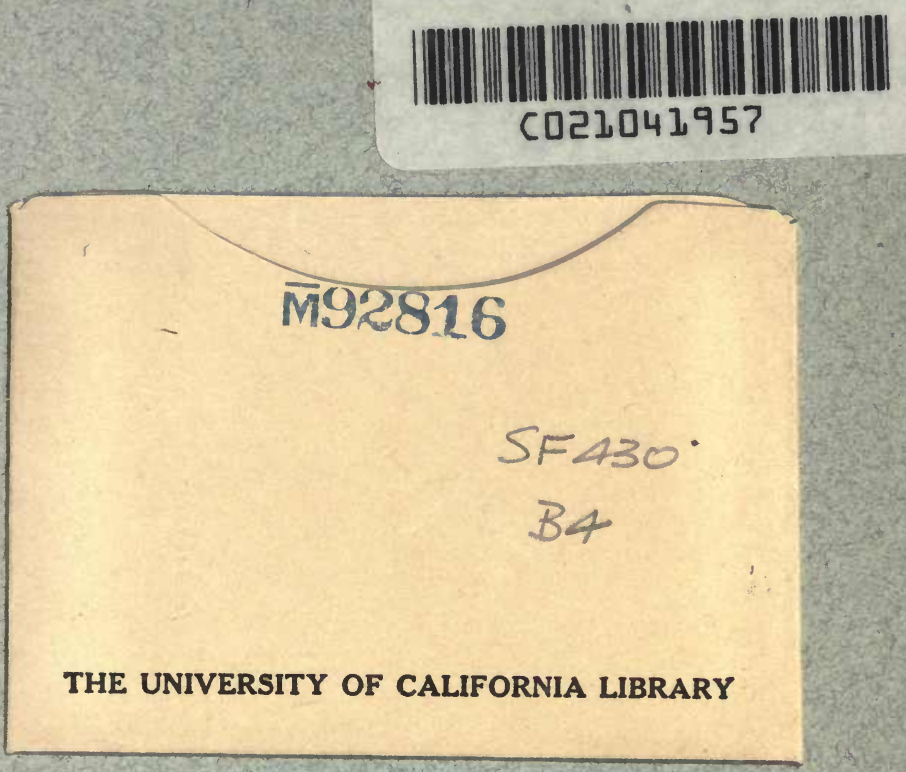

THE UNIVERSITY OF CALIFORNIA LIBRARY 
